\title{
The effect of intemational sporting event marketing mix (7Ps) on foreign spectators' destination image, satisfaction and revisit intention: An empirical evidence from 2019 Gwangju FINA World Championships
}

\author{
Doo-Sik Min \\ Hanyang University
}

\begin{abstract}
[Purpose] Limited research has investigated the marketing mix of international sporting events empirically. This study filled this gap by identifying the marketing mix and examined the structural relationships among marketing mix, destination image, satisfaction and revisit intention focusing on foreign spectators of 2019 Gwangju FINA World Championships. [Methods] The questionnaire was structured in four sections: sporting event marketing mix (seven dimensions and 21 items), host city image (three items), satisfaction (three items) and revisit intention (three items). Analysis of data from 396 foreign spectators in FINA Championships indicated that the proposed model fit the data well. Within a attitude-behavior theoretical framework, this study proposed and tested a structural relationships among the constructs. [Results] The results of this study presented that (1) product, place, and people in sporting event marketing mix significantly impacted foreign spectators' destination image, (2) product, price, place, promotion, and physical evidence were appeared to be significant predictors of satisfaction, and (3) destination image and satisfaction had a significant effect on foreign spectators' revisit intention. [Conclusion] The findings suggest marketing mix for the international sporting event and its influential mechanism on foreign spectators' revisit intention. Practically, this study provides important implications for event organizers that can be utilized to develop strategic marketing mix in sporting events to enhance spectators' destination image, satisfaction, and revisit intention.
\end{abstract}

Keywords: sporting event marketing mix, destination image, satisfaction, revisit intension, FINA

\section{서 론}

2019년 한국을 방문한 외래관광객은 역대 최대인 1,750 만명이다. 2018 년에 비해 약 $14 \%$ 증가했다(KTO, 2020). 중국관광객에 대한 의존도가 감소했으며 미국관 광객이 최초로 100 만명을 넘어섰다(MCST, 2019). 아 시아를 비롯한 중동, 미주 등 지역별 타깃 마케팅과 더불

논문 투고일 : 2020. 09. 28.

논문 수정일 : 2020. 11. 10.

게재 확정일 : 2020. 12. 03.

* 교신저자 : 민두식(doosik.min@gmail).
어 문화, 식도락, 생태 등과 관련한 다양한 관광 콘텐츠가 관광객 유치의 기반이 됐다는 평이다.

2019년 7월 12일부터 28일까지 17일간 광주에서 개 최된 FINA 세계수영선수권대회와 세계수영마스터스대 회 또한 외래관광객을 끌어 모으기 위한 주요 콘텐츠였 다. 세계수영선수권대회는 191 개 국가에서 7,456 명의 선수단이 참가했고, 마스터스대회에는 84개국에서 5,365 명이 참가해 총 1 만 2,821 명으로 집계됐다. 경기 장을 찾은 관람객 수는 33만 명에 달했다(Kim, 2019). 관중수용능력이 중요한 경영과 다이빙 종목은 주경기 
장인 남부대 시립수영장에서 치러졌다. 관람시설이 3,393석에서 10,648석 규모로 증축되고 운영시설 또한 2 배 이상 확대됐다. 수영대회의 꽃이자 광주의 아름다움 을 보여줄 하이다이빙 경기장은 조선대 본관 앞에 설치됐 다. 건축적 의미를 인정받은 고딕양식의 본관을 배경으 로, $27 \mathrm{~m}$ 높이에서 펼쳐지는 하이다이빙 퍼포먼스와 광 주시내를 내려다 볼 수 있었다(Yu, 2019).

라이브 사이트라는 대형 스크린으로 외국어 자막과 함 께 대회 정보를 제공하고 대회장에 안내로봇을 배치하여 관광객의 흥미를 이끌었다. 수영대회뿐 아니라 대회 전후 로 K-pop 슈퍼콘서트, 각종 문화예술축제, 민속문화체험 등이 펼쳐졌다. 광주시는 대회 전후 31 일간 대회장 인근 곳곳에 공연장을 설치하여 다채로운 행사를 마련하고 특 히 외래관광객들이 국악 상설공연은 물론 참가국의 전통 문화 공연, 한국음식 만들기 체험 등을 즐길 수 있도록 하 였다(Gwangju city, 2019).

한편, Fourie and Santana-Gallego(2011)는 하계올 림픽이나 FIFA월드컵에 비해 동계올림픽, 크리켓월드 컵, 럭비월드컵 등 전 세계적으로 이목을 끌지 못하는 메 가 이벤트는 개최지역에 의미있는 기여를 하지 못한다고 지적하였다. Dong and Duysters(2015) 또한 모든 국제 스포츠이벤트가 도시이미지 형성이나 지역경제 활성화 등과 관련하여 항상 긍정적인 효과만 가져오는 것은 아니 라고 주장했다. 외래관광객 유입측면에서 볼 때 국제스포 츠이벤트는 특정기간 동안만 열리고, 자국 선수들을 응원 하러 오는 경우가 많기 때문에 관광객 유치효과가 한정적 이며, 오히려 지방자치단체와 지역주민에게 장기간에 걸 쳐 과중한 재정부담을 안겨줄 수 있다는 것이다(Chung, 2008; Roche, 1994).

그럼에도 불구하고 여러 실증적 연구는 국제스포츠이 벤트가 관광객들에게 기억에 남을만한 관람경험을 제공 하여 중장기적으로는 외래관광객 유입에 기여한다고 밝 히고 있다(Aaker, 1991; Chalip, Green, \& Hill, 2003; Getz, 1997). 아울러, 재정과 관련해서 광주 세계수영선 수권대회의 경우 평창동계올림픽 (4조 2,835 억원) 대비 $4.8 \%$ 의 사업비(2,036억원)가 투입되었고, 대회운영과 관련해서는 1,367 억원의 수입 대비 1,208 억원을 지출하 여 159억원의 흑자를 남겨(Son, 2020), 막대한 재정투 입 없이 대회개최가 가능함을 증명했다. 이처럼 광주시는
적은 예산, 북한의 불참, 국내 스타선수의 부재라는 악재 에도 불구하고 이 대회를 통해 광주시가 젊음과 스포츠가 어우러진 역동적인 도시, 한국을 대표하는 수영도시로 발 돋움하는 계기를 마련했다고 밝혔다(Koo, 2019). 또한 대회의 성공개최를 발판삼아 한국 수영진흥센터 건립, 전 국 규모 수영대회 창설 등의 후속 문화유산(legacy)사업 을 추진하고 있다(Park, 2020). 단순한 숫자와 실적만을 앞세우는 전시성 이벤트가 아니라 중장기적 안목에서 꾸 준한 투자를 기반으로 타지역 및 외국인들이 방문하고 싶 은 브랜드화된 도시이미지를 구축하기 위한 노력이라 볼 수 있다(Kim, Nam, \& Byun, 2016).

이처럼 대규모 국제스포츠이벤트는 성공적인 개최 그 자체뿐만 아니라 개최도시(host city)의 이미지 제고를 통해 도시브랜드의 가치를 상승시키는 중요한 마케팅수 단으로 활용되고 있다(Min \& Lee, 2019; Zhang et al., 2018). 지방자치단체의 경우 대규모 국제스포츠이벤트 유치경쟁부터 개최도시에 대한 국내외 인지도를 높일 수 있고, 스포츠이벤트 이미지와 일치되는 개최도시 이미지 를 구축하게 될 경우 신규 관광객 유치와 기존 관광객의 재방문을 높을 수 있다(Aaker, 1991). 관광객들에게 스 포츠이벤트와 개최도시가 하나의 브랜드 제품으로 인지 되어 관광지 선정 시 중요한 요소로 작용하는 것이다 (Ross-Wooldrige, Brown, \& Minsky, 2004).

스포츠이벤트가 갖는 개최효과로 스포츠이벤트는 관 광산업의 주요 콘텐츠로 각광받게 되었고, 다수의 지방자 치단체는 스포츠이벤트 유치를 위해 지속적으로 경쟁하 고 있다(Getz, 1991). 하지만 2019년 기준 지방자치단 체가 개최하는 국제스포츠이벤트만 수십여 개에 이르고, 수많은 스포츠이벤트로 인해 개최도시가 제공하는 서비 스가 전반적으로 동질화, 평준화되고 있는 실정이다. 이 런 맥락에서 개최도시이미지 제고는 물론, 국내외 관광객 확대와 지역경제 활성화 등의 스포츠이벤트 개최효과를 창출하기 위해서는 스포츠이벤트의 특성을 고려한 최적 의 마케팅 전략을 수립하고 이벤트 개최 전·후에 걸쳐 체 계인 마케팅활동을 추진하는 것이 무엇보다 중요한 상황 이다.

다수의 학자에 따르면 마케팅전략 수립은 제품이나 서 비스에 최적화되고 상호보완이 가능한 마케팅믹스 (marketing mix) 요인을 발굴하여 적용하는 것에서 시 
작한다(Booms \& Bitner, 1981; Bordern, 1964; Moutinho \& Witt, 1989). 마케팅믹스는 전통적으로 제품 (product), 가격 (price), 장소(place), 촉진 (promotion) 의 $4 \mathrm{P}$ 로 구성되며 주로 1 차 산업인 제조업을 대상으로 적용됐다(Kotler \& Keller, 2016). 하지만 3차 산업인 서비스업에 적합한 마케팅믹스의 필요성과 기존 마케팅 믹스가 갖는 한계에 기반하여 종사원 (people), 물리적 환 경 (physical evidence), 서비스과정 (process) 등이 추가 된 7P가 등장했다(Booms \& Bitner, 1981; Grönroos, 1987).

다른 서비스산업과 마찬가지로 스포츠 분야에서도 스 포츠소비자의 행동을 예측하기 위해 마케팅믹스를 소비 자행동의 선행변인으로 활용한 연구가 활발하게 진행되 고 있다. 스크린 스포츠 테마파크(Lee, Jeon, \& Kim, 2017), 상업스포츠센터(Kim \& Han, 2016; Yoon \& Chang, 2009) 등 참여스포츠 분야부터 무용공연(Kim, Kim, \& Kim, 2020), 체조갈라쇼(Kim, Yoo, \& Park, 2016), e-스포츠 대회(Choi, 2019), 프로야구(Kang, 2017), 프로축구(Cho \& Ha, 2020; Kwon \& Jeng, 2015), 피겨스케이팅공연(Park, 2009), F1 그랑프리 (Kim, Park, \& Kim, 2016; Kwon, Lee, \& Kim, 2013) 등 관람스포츠 분야에 이르기까지 많은 연구들이 마케팅믹스가 관람만족, 재방문의도 등에 미치는 영향을 규명하였다. 선행연구는 전통적 $4 \mathrm{P}$ 에서부터 공중관계 (public relation) 등을 추가한 $5 \mathrm{P}$, 종사원이나 서비스과 정 등을 추가한 $7 \mathrm{P}$ 등에 이르기까지 다양한 마케팅믹스 요인을 제시하고 있다.

하지만 스포츠분야에서 마케팅믹스를 활용한 다수의 선행연구는 서비스산업임에도 불구하고 전통적 $4 \mathrm{P}$ 만을 주로 활용하고 있으며, 국제스포츠이벤트 분야 또는 외래 관광객을 대상으로 한 실증연구 또한 매우 부족한 상황이 다. 따라서 스포츠관광산업 측면에서 국제스포츠이벤트 의 중요성에 비추어볼 때, 국제스포츠이벤트에 적합한 마 케팅믹스 요인을 탐색해 보고 마케팅믹스와 관광객의 관 람만족, 관광지이미지, 행동의도 등 종속변인 간 관계를 규명하여 소비심리행동 측면에서 마케팅믹스의 역할과 영향력을 파악해 볼 필요가 있다. 이에 이 연구는 2019 광주 FINA 세계수영선수권대회에 참관한 외래관광객을 대상으로 개최도시이미지, 관람만족 등을 매개로 한 마케
팅믹스와 관광객의 재방문의도 간 관계를 살펴보고자 한 다. 이를 통해 국제스포츠이벤트의 효율적 마케팅믹스 전 략 수립과 개최목적 달성에 필요한 실증적 자료를 제공할 수 있을 것이다.

\section{이론적 배경 및 연구가설 설정}

\section{스포츠이벤트의 마케팅믹스}

마케팅믹스는 제품이나 서비스 구매에 영향을 미치고 궁극적으로 기업 또는 조직이 추구하는 경영성과를 달성 하기 위해 통제 가능한 마케팅 요소 또는 수단을 적절하 게 결합한 것이다(Kotler \& Keller, 2016; McCarthy, 1964). 표적시장의 고객을 만족시킬 수 있는 마케팅믹스 를 적절히 구성하여 마케팅전략을 추진했을 때 효과를 극 대화할 수 있다(Kotler \& Armstrong, 2012). Borden(1964)은 마케팅믹스를 최초로 제안하였고 McCarthy(1964)는 이를 일반화하여 전통적 마케팅믹 스인 제품(product), 가격 (price), 촉진 (promotion), 장 소(place) 등 $4 \mathrm{P}$ 를 제안했다. $4 \mathrm{P}$ 는 실무적으로도 유용한 개념적 프레임을 제공하고 있으며 여러 산업의 마케팅믹 스 활동을 쉽게 설명할 수 있다는 장점을 지닌다(Rafiq \& Ahmed, 1995).

하지만 문화, 예술, 스포츠 등 산업의 다양화를 비롯하 여 복잡한 산업구조의 등장으로 마케팅믹스의 확대가 요 구되었다(Lovelock, Patterson, \& Wirtz, 2015). 특히 생산과 소비자의 경험 및 소비가 동시에 발생하고 서비스 제공자와 소비자 간 접촉이 활발한 서비스업에서는 전통 적 마케팅믹스를 적용하는데 한계가 나타났다. 이에 Booms and Bitner(1981)는 무형재인 서비스업에 적합 한 마케팅믹스를 제안했다. 기존 $4 \mathrm{P}$ 에 참여자 (participants), 물리적 환경 (physical evidence), 서비 스과정 (process) 등 $3 \mathrm{P}$ 를 추가하였다. 여러 학자들은 이 후 참여자를 사람(people)으로 바꾸어 서비스 산업의 마 케팅믹스 7P로 활용하고 있다(Fisk, Brown, \& Bitner, 1993).

스포츠이벤트 또한 일반적인 유형재와는 달리 무형성 (intangibility), 소멸성(perishability), 생산과 소비의 
동시성(simultaneity) 등의 특성을 지닌다(Pedersen, Miloch, \& Laucella, 2007). 특히 스포츠소비자에게 소 유하거나 간직할 수 있는 물리적 제품이 아닌 스포츠를 통해 오락·일탈·교육 등 무형적인 다양한 경험을 제공한 다(Buhler \& Nufer, 2009; Pine \& Gilmore, 1999). 이러한 특성으로 인해 스포츠이벤트의 마케팅믹스는 유 형재를 대상으로 하는 전통적 $4 \mathrm{P}$ 가 아닌 서비스마케팅 관점에서 제시된 종사원, 서비스과정, 물리적 환경 등을 추가적으로 활용해야 할 필요성이 증대되고 있다(Kwon et al., 2015). 이에 따라 Baek and Kim(2016)의 경우 변형된 마케팅믹스 $4 \mathrm{P}$ 인 참여가치, 편리성, 비용, 커뮤니 케이션 외 프로야구 관람시 중요하다고 판단되는 고객안 전, 조화 등을 추가한 $6 \mathrm{P}$ 를 제시하였고, $\mathrm{Kim}$ and $\operatorname{Park}(2014)$ 은 K리그 구단의 효율적 마케팅믹스로 선수 단, 입장권·부대시설 가격, 경기장.부대시설, 스폰서십과 프로모션 외에 공중관계, 인적자원, 시설물 등을 추가적 으로 발굴하였다. 무용공연장 마케팅믹스 요인을 밝힌 Lee et al.(2012)의 연구는 서비스마케팅믹스 7P를 변 형하여 작품, 관람요금, 공연장, 프로모션, 공연관계자, 진행과정, 물리적 환경 등을 제시하였다.

이처럼 스포츠이벤트의 마케팅믹스와 관련한 선행연 구에 따르면 먼저 스포츠이벤트의 제품은 스포츠경기와 관련된 유·무형의 재화와 서비스를 아우르는 개념으로 관람객 입장에서 스포츠이벤트가 갖는 핵심 이점 (benefit)이라 할 수 있다(Kotler \& Armstrong, 2012). 관람객들은 스포츠이벤트를 통해 오락과 즐거움 (entertainment), 일상에서의 일탈(escapism), 이벤트 가 주는 아름다움(esthetics) 등을 경험하려고 하는데 (Min, Ko, \& Lee, 2020), 이에 따라 스포츠이벤트의 제 품은 재미있는 경기 그 자체뿐 아니라, 유명한 선수들의 출전, 선수들의 기량, 경기장 내 분위기, 하프타임 쇼 등 으로 확대할 수 있다(Mullin, Hardy, \& Sutton, 2014). 가격은 제품이나 서비스를 얻기 위해 지불하는 비용으 로 마케팅을 통한 고객유인 측면에서 기업이 활용할 수 있는 가장 강력한 마케팅믹스다(Kotler \& Armstrong, 2012). 스포츠이벤트에서는 경기관람을 위한 입장료, 경 기장 외 부대시설을 이용하면서 지출하게 되는 부대비용 을 비롯하여 좌석이나 관람시간 등에 따른 차별화된 티 켓, 쿠폰 또는 할인혜택 등 가격의 효용성, 합리성, 경제
성까지 내용을 확장할 수 있다(Kwon et al., 2013; Lee et al., 2012). 장소의 경우 제조업에서는 제품이 만들어 지고 유통되는 경로 등으로 설명되지만 스포츠이벤트 분 야에서는 주로 경기시설을 말하며 청결하고 잘 정돈된 경 기장과 안락한 좌석 외에 경기장의 위치와 접근성, 대중 교통, 주차, 안내표시 등을 포함한다(Wakefield \& Blodgett, 1994, 1996). 프로모션은 표적시장의 소비자 에게 제품이나 서비스에 대한 이점을 설명하고 구매를 유 도하기 위한 마케팅믹스 요인이다(Kotler \& Armstrong, 2012). 스포츠이벤트의 프로모션은 경기관 람을 활성화하기 위한 TV, 인터넷 등을 통한 광고, 홍보 등과 함께 포스터나 브로셔 등을 통해 관람객들에게 제 공 되는 선수, 경기 관련 다양한 정보가 주요 요소다(Kwon et al., 2013).

이상의 전통적 $4 \mathrm{P}$ 외에 서비스마케팅에서 주목하는 확장된 마케팅믹스 요인은 먼저 사람이다. 보통 서비스를 제공하는 종사원과 관련된 사항이다. 스포츠이벤트에서 는 관람객들에게 서비스를 제공하는 경기 운영인력, 티켓 이나 기념품 판매시설 운영인력, 주차요원 등이 대상으 로, 이들의 전문성, 친절성, 배려, 문제해결력과 같은 요 인으로 세분화할 수 있다. 이는 서비스-마케팅 분야에서 폭넓게 사용되고 있는 서비스품질 평가척도인 SERVQUAL(Parasuraman, Zeithaml, \& Berry, 1988)의 신뢰성, 확신성, 공감성과 유사한 맥락이다. 그 다음으로 서비스과정은 서비스 제공에 필요한 절차 또는 활동으로 얼마나 효율적으로 고객에게 서비스가 전달되 는지를 의미한다. 스포츠이벤트에서는 입.퇴장의 통제, 경기진행, 안전관리, 문제해결 등이다(Kim et al., 2020; Lee et al., 2012). 마지막으로 서비스의 성과를 촉진할 수 있는 물리적 환경은 디자인, 온도, 조명, 소음 등 분위기(ambience)나 레이아웃(layout), 부대시설·편 의시설의 이용편리성 등을 말한다(Hoffman \& Bateson, 2010).

\section{마케팅믹스와 개최도시이미지와의 관계}

Crompton(1979)은 관광지의 지역이미지 (destination image)를 관광객들이 갖고 있는 인지적 믿 음(beliefs)과 아이디어(ideas), 정서적 인상 
(impressions)의 합이라 정의하였다. 이에 기반하여 Baloglu and Brinberg(1997) 또한 지역이미지를 관광 객이 어떤 지역을 방문, 관광하려고 고려했을 때 그 지역 에 대해 떠오르는 아이디어(ideas), 믿음(beliefs), 생각 (thoughts), 인상(impressions) 등 관광지에 대한 전반 적인 지각(overall perceptions)이라 정의하였다. Worcester(1997)는 지역이미지가 관광지에 대한 인상, 경험, 정서, 신념 그리고 지식들의 상호작용 결과로 형성 된다고 주장했다. 이에 기반하여 스포츠이벤트의 개최도 시이미지는 스포츠이벤트가 열리는 지역에 대해 관람객 들이 갖는 주관적 신념, 인상이라 할 수 있다.

스포츠이벤트는 이벤트 전후 끊임없는 미디어노출을 통해 관람객들의 호기심을 자극하고 이들을 개최도시로 이끌게 된다(Chalip et al., 2003). 그리고 스포츠이벤트 개최도시에 대한 스포츠소비자의 긍정적 이미지는 향후 관광목적지 선택과정에서 중요한 요인으로 작용한다. 이 에 따라 관광산업분야에서는 지역이미지를 관광객의 재 방문 의도, 타인추천 등 행동의도에 영향을 미치는 중요 한 요인으로 간주하고 지속적으로 연구가 진행되고 있다 (Kaplinidou \& Vogt, 2007; Mackay \& Fesenmaier, 2000).

스포츠와 관광산업에서 지역이미지의 선행요인으로 마케팅믹스를 활용한 연구를 살펴보면, 먼저 Lee and $\operatorname{Kim}(2016)$ 의 경우 전남지역 L골프장 이용객을 대상으 로 한 연구에서 골프관광의 마케팅믹스 요인이 골프장 이 미지에 영향을 미친다고 보고하였다. Mun and Cho(2011)는 스포츠시설 마케팅믹스가 스포츠시설 이 미지에 긍정적인 영향을 미치는 요인이라고 밝혔다. 제주 도 관광객을 대상으로 한 Yoon and $\operatorname{Lim}(2009)$ 의 연구, 컨벤션센터 방문객을 대상으로 한 Hwang et al. (2015) 의 연구 또한 마케팅믹스가 지역이미지에 긍정적인 영향 을 미치는 선행요인이라 규명하였다.

이 연구는 상기 선행연구에 기반하여 다음과 같이 연 구가설을 설정하였다.

$\mathrm{H1}$ : 광주 세계수영선수권대회의 마케팅믹스(7P)는 외래방문객의 개최도시이미지에 긍정적인 영향 을 미칠 것이다.

\section{마케팅믹스와 관람만족과의 관계}

일반적으로 만족(satisfaction)은 고객의 소비활동 참 여에 궁극적인 목적이 되는 개념으로 소비자의 사후행동 을 예측하는 중요한 결정요인으로 활용되고 있다(Baker \& Crompton, 2000). Oliver(1997)에 따르면 만족은 고객이 제품, 서비스를 제공받은 후 평가하게 되는 판단 으로, 욕구가 충족되거나 제공받기 전의 기대한 가치 또 는 그 이상을 얻게 됐을 때 갖게 되는 긍정적인 감정이다. 따라서 스포츠이벤트의 관람만족은 스포츠이벤트가 제 공하는 제품·서비스 등을 경험한 관람객이 시간의 흐름에 따라 만족상태에 도달했는지에 대한 평가로 스포츠이벤 트 관람활동에 대한 긍정적 인식이라 할 수 있다(Min \& Lee, 2019).

스포츠분야에서 마케팅믹스와 만족 간의 관계를 고찰 한 선행연구를 살펴보면, 먼저 Kim et al.(2020)은 국립 무용단의 컨버전스 무용공연 관람객 473 명을 대상으로 한 연구를 통해 무용공연의 진행과정, 공연작품, 공연관 계자 등이 관람만족에 긍정적인 영향을 미친다고 규명하 였다. Kwon et al. (2013)은 F1 그랑프리 관람객에 대한 연구에서 제품, 장소, 촉진 등의 마케팅믹스 요인이 관람 만족에 긍정적 영향을 미친다고 밝혔다. 이밖에도 프로야 구단 관람객에 대한 Lee et al.(2017), Roh, Kim, and $\operatorname{Park}$ (2012)의 연구, 프로축구 관람객에 대한 Cho and $\mathrm{Ha}$ (2020), Kwon and Jeng(2015)의 연구, e-스포츠 관 람객에 대한 Choi(2019)의 연구 등은 마케팅믹스가 관 람만족의 중요한 선행요인임을 밝히고 있다.

이 연구는 상기 선행연구에 기반하여 다음과 같이 연 구가설을 설정하였다.

$\mathrm{H} 2$ : 광주 세계수영선수권대회의 마케팅믹스(7P)는 외래방문객의 관람만족에 긍정적인 영향을 미칠 것이다.

\section{개최도시이미지와 재방문의도와의 관계}

관광산업에서 재방문 관광객은 매우 중요한 고객층 (market segment)이다. 이들은 신규 방문객보다 마케 팅비용이 적게 소요되는 반면 해당지역에 더 오래 머무는 
경향이 있고 소비활동이 더욱 활발하며 긍정적인 구전효 과도 강하기 때문이다(Lehto, O'Leary, \& Morrison, 2004; Oppermann, 2000). 따라서 관광활성화 측면에 서 관광객의 재방문의도(revisit intention)를 파악하고 이에 영향을 미치는 요인들을 관리하는 것이 요구된다.

재방문의도는 행동의도(behavioral intention)에서 도출된 개념이다. 행동의도는 소비심리행동을 예측하고 대변하는 핵심요소로(Fishbein \& Ajzen, 1975), 재방 문의도, 지속방문의도, 재구매의도 등 행동적 의도와 타 인추천, 긍정추천 등 구전의도 등으로 세분화할 수 있다 (Oliver, 1997). 여가와 관광측면에서 행동의도는 보통 5년 내에 해당지역을 재방문하려는 의도나 해당지역을 종종 여행해 보고자 하는 의지 등 재방문의도와 크게 관 련이 있다(Baker \& Crompton, 2000). 이에 따라 이 연 구 또한 스포츠이벤트 관람객의 미래행 동의도 중 관광지 역 재방문의도를 핵심적인 변수로 활용하였다.

여러 연구는 스포츠이벤트와 관련된 지역이미지는 관 람객들의 관람소비 의사결정, 방문지역 결정 등에 큰 영향 을 미치는 요인이라 밝히고 있다(Echtner \& Ritchie, 2003). Kim et al.(2016)은 Formula 1 Chinese Gran Prix 관람객을 대상으로 한 연구를 통해 지역이미지가 방 문객의 재방문의도에 긍정적 영향을 미친다고 보고했다. 미국 남부 마라톤대회 참여자를 대상으로 한 Kaplanidou et al. (2012)의 연구 또한 지역이미지가 지역 재방문의도 에 영향을 미친다고 밝혔다. Dongfeng(2013)의 경우 스 포츠이벤트를 앞두고 상하이를 방문한 외래관광객을 대상 으로 한 연구에서 지역이미지가 재방문의사의 유의한 선 행요인임을 규명하였다. 이밖에 이란 마잔다란 지역의 해 양스포츠 관광객을 대상으로 한 Allameh et al.(2014)의 연구, 투르 드 코리아 관람객을 대상으로 한 Min and Lee(2019), Moon et al.(2013)의 연구 등 또한 지역이 미지가 재방문의도에 긍정적 영향을 미친다고 밝혔다.

이 연구는 이상의 선행연구가 밝힌 개최도시이미지와 재방문의도 간의 관계에 근거하여 다음과 같은 연구가설 을 설정하였다.

$\mathrm{H} 3$ : 광주 세계수영선수권대회 개최도시이미지는 외 래관광객의 재방문의도에 긍정적인 영향을 미칠 것이다.

\section{관람만족과 재방문의도와의 관계}

스포츠이벤트와 관련하여 관람만족은 스포츠이벤트품 질, 스포츠이벤트 물리적 환경, 스포츠이벤트 속성 등의 선행요인과 관람객의 행동의도를 연결하는 매개변수로 연구되어 왔다. 특히 다수의 스포츠이벤트 분야 연구에서 는 관람만족이 높을수록 지역재방문의도, 타인추천 등의 행동의도가 높아진다고 밝혀졌다(Cho \& Ha, 2020; Choi, 2019; Kim et al, 2016; Kim et al., 2020; Lee et al., 2012; Min \& Lee, 2019; Roh et al., 2012).

이 연구는 이상의 선행연구가 밝힌 관람만족과 재방문 의도 간의 관계에 근거하여 다음과 같은 연구가설을 설정 하였다.

$\mathrm{H} 4$ : 광주 세계수영선수권대회 관람만족은 외래관광객 의 재방문의도에 긍정적인 영향을 미칠 것이다.

위에서 밝힌 4가지 가설을 바탕으로〈Figure 1)과 같 이 연구모형을 도식화하였다.

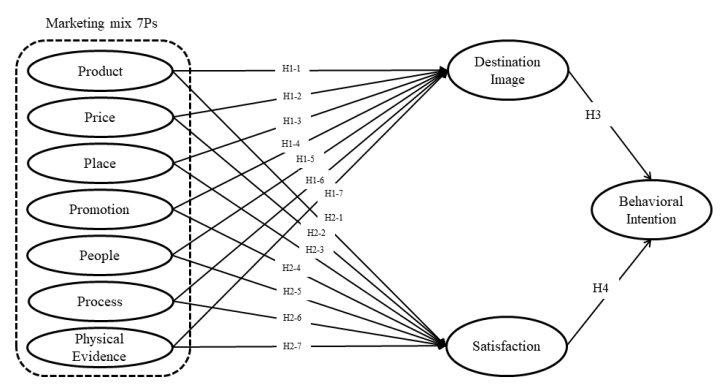

Fig.1. The proposed hypothetical model

\section{연구방법}

\section{연구대상 및 표본수집}

이 연구는 2019 광주 FINA 세계수영선수권대회 관람 을 위해 외국에서 입국하여 광주를 방문한 외래관광객을 모집단으로 하였다. 대회기간 중 2019년 7월 15일부터 27일까지 남부대학교의 경영과 수구 경기, 조선대학교의 
하이다이빙 경기를 관람하는 외래관광객을 대상으로 편 의표본추출법을 이용하여 총 415 명을 표집하였다. $1: 1$ 대인면접으로 설문조사의 목적과 주요 내용 등을 설명하 고, 자기평가기입법에 기반하여 설문지를 작성하도록 했 다. 전체 문항 중에서 $10 \%$ 이상이 누락되거나 동일한 응 답 등으로 신뢰성이 낮다고 판단된 16 부를 제외하고, 396부를 최종표본으로 사용하였다.

396 명 중 남성은 227명(57.3\%), 여성은 169명 (42.7\%)이다. 연령은 20대 137명(34.6\%), 30대 87명 (22.0\%), 50대 80명 (20.2\%), 40대 65명 (16.4\%), 60 대 이상 27 명 $(6.8 \%)$ 순으로 나타났다. 국적은 4 개 대륙 별로 구분하면 독일·스페인.영국 등 유럽이 141 명 $(35.6 \%)$ 으로 가장 많았고 중국.일본말레이시아 등 아시 아 117 명 $(29.6 \%)$, 미국·캐나다 등 미주 73 명 $(18.4 \%)$, 아프리카 65 명 $(16.4 \%)$ 순이다. 직업의 경우 사무직 86 명 $(21.7 \%)$, 학생 81 명 (20.5\%), 전문직 46명 (11.6\%) 등이고 군인, 예술가 등 기타 직업군이 55 명 (13.9\%)이 었다. 월소득은 USD 8,000 이상이 91명 (23.0\%)으로 가장 많았고 USD 3,000 미만 86명(21.7\%), USD 2,000 미만이 84 명 $(21.2 \%)$ 으로 나타났다. 연구대상자 의 일반적 특성에 대한 내용은 〈Table 1)과 같다.

\section{조사도구}

이 연구는 신뢰성과 타당성이 입증된 선행연구 문항을 기초로 하여 구조화된 영문 설문지를 구성한 후 조사에 사용하였다. 마케팅믹스 요인 중 $4 \mathrm{P}$, 개최도시이미지, 관 람만족, 재방문의도 등은 선행연구의 영문 설문을 연구에 맞도록 수정·보완하였고, 국문으로 된 일부 마케팅믹스 조사도구는 영문으로 번역한 후 전문가 검수를 거쳐 사용 하였다. 마케팅믹스는 Kim et al.(2016), Kwon et al. (2018), Lee et al(2012) 등이 사용한 설문문항으로 부터 제품( 5 개 문항), 가격 (3개 문항), 장소( 5 개 문항), 프로모션(4개 문항), 종사원 (3개 문항), 서비스과정 (3개 문항), 물리적 환경 (3개 문항) 등 7 개 차원 27 개 항목을 도출하였다. 개최도시이미지와 관람만족은 각각 Byon and Zhang(2009)의 연구와 Oliver(1997) 등의 연구를 활용하여 단일차원의 3 개 항목으로 구성하였다. 재방문 의도는 Zeithaml et al.(1996), Zhang et al.(2018) 등
Table 1. Demographic characteristics $(N=396)$

\begin{tabular}{|c|c|c|c|}
\hline \multicolumn{2}{|c|}{ Variables } & $\mathrm{N}$ & Frequency $(\%)$ \\
\hline \multirow{2}{*}{ Gender } & Male & 227 & 57.3 \\
\hline & Female & 169 & 42.7 \\
\hline \multirow{5}{*}{ Age } & $20-29$ & 137 & 34.6 \\
\hline & $30-39$ & 87 & 22.0 \\
\hline & $40-49$ & 65 & 16.4 \\
\hline & $50-59$ & 80 & 20.2 \\
\hline & $\geqq 60$ & 27 & 6.8 \\
\hline \multirow{4}{*}{ Continent } & Asia & 117 & 29.6 \\
\hline & Africa & 65 & 16.4 \\
\hline & America & 73 & 18.4 \\
\hline & Europe & 141 & 35.6 \\
\hline \multirow{7}{*}{ Occupation } & Office worker & 86 & 21.7 \\
\hline & Engineer & 34 & 8.6 \\
\hline & Professional & 46 & 11.6 \\
\hline & Sales, service & 77 & 19.4 \\
\hline & Self-employed & 17 & 4.3 \\
\hline & Student & 81 & 20.5 \\
\hline & Others & 55 & 13.9 \\
\hline \multirow{8}{*}{$\begin{array}{l}\text { Monthly } \\
\text { House } \\
\text { Income }\end{array}$} & $<$ USD 2,000 & 84 & 21.2 \\
\hline & $<$ USD 3,000 & 86 & 21.7 \\
\hline & $<$ USD 4,000 & 31 & 7.8 \\
\hline & $<$ USD 5,000 & 24 & 6.1 \\
\hline & $<\operatorname{USD} 6,000$ & 21 & 5.3 \\
\hline & $<$ USD 7,000 & 27 & 6.8 \\
\hline & $<$ USD 8,000 & 32 & 8.1 \\
\hline & $\geqq$ USD 8,000 & 91 & 23.0 \\
\hline
\end{tabular}

의 연구를 바탕으로 단일차원의 3 개 항목으로 구성하였 다. 이상의 문항에 대해 리커트(Likert) 7점 척도(1=전 혀 그렇지 않다, $7=$ 매우 그렇다)로 측정하였다. 모든 설 문지는 스포츠마케팅 관련 교수 2 인을 포함 5 인의 전문 가 회의를 거쳐 내용과 구성의 적합성, 적용가능성 등을 검토하였다.

\section{자료처리}

이 연구는 설문조사를 통해 표집된 415 부 중 16 부를 제외하고 총 396부를 최종분석용 유효표본으로 선정하 
였다. 유효표본 응답내용을 부호화한 이후 연구목적에 따라 각각을 분석하였다. 먼저 SPSS 22.0 을 사용하여 빈도분 석(frequency analysis), 탐색적 요인분석 (exploratory factor analysis), 신뢰도 분석을 실시하였다. 통상 이론 적으로 요인구조가 명확할 때 탐색적 요인분석을 생략하 고 확인적 요인분석으로만 진행할 수 있으나, 잠재변수와 관측변수의 수가 많고 확인적 요인분석 과정에서 모형의 수정과 검증의 반복을 효과적으로 줄이기 위해 탐색적 요 인분석이 선행되는 경우가 있다(Kelloway, 1995). 이에 따라 스포츠이벤트 마케팅믹스 7P 조사도구에 대해 요인 적재치가 높은 명확한 요인모형을 도출하기 위하여 최대 우도법(maximum likelihood)을 활용한 요인분석을 실 시하고 사각회전방식 중 직접 오블리민 (direct oblimin) 을 통해 요인적재치를 단순화했다. 요인추출 기준은 고유 값(eigen value) 1.0 이상으로 하였다. 요인적재값은 일 반적으로 .3이상이면 통계적으로 의미가 있다고 판단되 지만 보수적 기준으로 4 이상으로 선정했다(Hair et al., 2010). 아울러 2개 요인에 .4이상으로 교차적재될 경우 이를 설문항목에서 제외하였다(Hair et al., 2010). 도출된 요인에 대해서는 신뢰도를 분석하였는데 신뢰도는 Cronbach $a$ 값 .7 이상을 컷오프 기준으로 적용 하였다(Nunnally \& Bernstein, 1994).

AMOS 22.0 을 사용하여 수집된 데이터의 모델적합도 평가, 집중타당도 검증 등을 진행하고 확인적 요인분석 (confirmatory factor analysis)을 활용하였다. 모델적 합도는 여러 학자가 하나 이상의 지수를 사용하길 권고하 고 있으며 (Hair et al., 2010), 이 연구는 현재 널리 사용 되고 있는 모델적합도 지수를 사용하였다. 통상 $\chi^{2} / d f$ 의 경우 샘플 사이즈가 200개 이상일 경우 결과 수치가 매우 민감해지기 때문에 Wheaton(1987)이 제시한 5 이하를 적합도 기준으로 사용하였다. 이밖에 Comparative Fit Index(CFI)와 Tucker-Lewis Index(TLI)는 .9 이상, Standardized Root Mean Square Residual(SRMR)과 Root Mean Square Error of Approximation(RMSEA) 는 .10 이하를 사용하였다(Bentler, 1990; $\mathrm{Hu} \&$ Bentler, 1999. Shevlin \& Miles, 1998). 마지막으로 세계수영선수권대회 마케팅믹스 요인과 외래관람객의 개최도시이미지, 관람만족, 재방문의도 간 영향관계를 파악하기 위하여 구조방정식모형분석 방법(structural equation modeling analysis)을 활용하였다. 모든 통계 적 유의수준은 $p<.05$ 로 설정했다.

\section{연구결과}

\section{조사도구의 타당도 및 신뢰도 분석}

먼저 SPSS 22.0 을 활용하여 마케팅믹스 조사도구에 대해 탐색적 요인분석을 실시한 결과 $\mathrm{KMO}$ (Kaiser-MeyerOlkin) 표본적합성은 .875, Bartlett 구형성 검정은 $8414.978, d f=253, \mathrm{Sig}=.000$ 으로 나타나 데이터가 요 인분석에 적합함을 확인하였다(Hair et al., 2010). 〈Table 2〉에서 제시된 바와 같이 마케팅믹스 요인은 7개 차원으로 도출되었으며, 이는 제품(product), 가격 (price), 장소(place), 촉진(promotion), 종사원(people), 서비스과정(process), 물리적 환경(physical evidence) 이다. 패턴행렬과 구조행렬을 통해 분석한 결과, 교차적 재된 3 개 문항(제품 1 개 문항, 장소 2 개 문항)과 요인적 재값이 .4미만인 2개 문항(제품 1 개 문항, 프로모션 1개 문항)을 제외하였다. 이에 따라 마케팅믹스는 최종적으 로 총 21 개 문항이 사용되었다. 마케팅믹스, 개최도시이 미지, 관람만족, 재방문의도 등 모든 요인의 표준적재치 는 최저 .708에서 최고 .957로 나타났으며 신뢰도 또한 최저 .858에서 최고 .956으로 컷오프 기준인 .7을 초과 하여 연구대상의 응답내용이 내적일관성을 확보하는 것 으로 밝혀졌다.

확인적 요인분석의 시행 결과, $\mathrm{CMIN}=1438.487$, $d f=354$ 로 $\quad \chi^{2} / d f=4.064$ 로 나타났고 $\quad \mathrm{CFI}=.915$, $\mathrm{TLI}=.896, \quad \mathrm{SRMR}=.060, \mathrm{RMSEA}=.088$ 로 나타나 TLI를 제외한 모든 모형적합도 지수가 수용기준을 충족 하였다. TLI 또한 .9에 근접하기 때문에 수용가능한 수치 라 볼 수 있다(Bentler, 1990; Hu \& Bentler, 1999. Shevlin \& Miles, 1998; Wheaton,1987).

집중타당도를 검증하기 위해 평균분산추출(AVE, average variance extracted)과 개념신뢰도(CR, composite reliability)를 사용하였다(Fornell \& Larcker, 1981). 평균분산추출값의 기준은 .5이상, 개념신뢰도 값의 기준은 .7이상을 적용했다(Fornell \& Larcker, 
Table 2. Results of the exploratory factor analysis and the confirmatory factor analysis

\begin{tabular}{|c|c|c|c|c|c|c|}
\hline Dimension & Items & $\begin{array}{l}\text { Mean } \\
\text { (SD) }\end{array}$ & $\begin{array}{c}\text { Standardized } \\
\text { coefficients }\end{array}$ & $\begin{array}{c}\text { Standard } \\
\text { error }\end{array}$ & $t$ & $\alpha$ \\
\hline \multirow{3}{*}{ Product } & This event was enjoyable. & $\begin{array}{l}6.157 \\
(.914)\end{array}$ & .734 & - & - & \multirow{3}{*}{0.913} \\
\hline & Skill performance of athletes in this event was excellent. & $\begin{array}{l}6.429 \\
(.831)\end{array}$ & .953 & .060 & 20.328 & \\
\hline & Various programs combined with the game were exciting. & $\begin{array}{l}6.366 \\
(.799)\end{array}$ & .941 & .058 & 20.793 & \\
\hline \multirow{3}{*}{ Price } & The ticket prices of this event were reasonable. & $\begin{array}{c}5.717 \\
(1.1652)\end{array}$ & .743 & - & - & \multirow{3}{*}{0.866} \\
\hline & $\begin{array}{l}\text { The price for the amenities and additional services } \\
\text { was reasonable. }\end{array}$ & $\begin{array}{l}5.217 \\
(1.414)\end{array}$ & .723 & .080 & 14.812 & \\
\hline & Various discount opportunities were available. & $\begin{array}{c}5.490 \\
(1.359) \\
\end{array}$ & .948 & .074 & 20.271 & \\
\hline \multirow{3}{*}{ Place } & $\begin{array}{l}\text { The stadium and facilities were clean } \\
\text { and well maintained. }\end{array}$ & $\begin{array}{c}5.735 \\
(1.246)\end{array}$ & .940 & - & - & \multirow{3}{*}{0.950} \\
\hline & The stadium and facilities were appropriate for this event. & $\begin{array}{c}5.947 \\
(1.104)\end{array}$ & .921 & 0.25 & 34.316 & \\
\hline & $\begin{array}{l}\text { The stadium was easily accessible and located } \\
\text { in a convenient place. }\end{array}$ & $\begin{array}{c}5.702 \\
(1.227)\end{array}$ & .931 & .27 & 35.707 & \\
\hline \multirow{3}{*}{ Promotion } & Mass media advertisements of this event were appealing. & $\begin{array}{c}5.833 \\
(1.209)\end{array}$ & .818 & - & - & \multirow{3}{*}{0.858} \\
\hline & Internet advertisements of this event were appealing. & $\begin{array}{l}5.775 \\
(1.185)\end{array}$ & .905 & .050 & 21.897 & \\
\hline & $\begin{array}{l}\text { Useful and up-to-date information about this event } \\
\text { was provided. }\end{array}$ & $\begin{array}{l}5.583 \\
(1.096) \\
\end{array}$ & .750 & .050 & 17.004 & \\
\hline \multirow{3}{*}{ People } & The event staff were courteous and friendly. & $\begin{array}{c}5.843 \\
(1.091)\end{array}$ & .905 & - & - & \multirow{3}{*}{0.871} \\
\hline & $\begin{array}{l}\text { The event staff handled problems promptly } \\
\text { and satisfactorily. }\end{array}$ & $\begin{array}{c}5.631 \\
(1.178)\end{array}$ & .828 & .045 & 21.772 & \\
\hline & The event staff were helpful. & $\begin{array}{c}5.846 \\
(1.143)\end{array}$ & .704 & .049 & 16.478 & \\
\hline \multirow{3}{*}{ Process } & This event operated smoothly. & $\begin{array}{c}4.995 \\
(1.429)\end{array}$ & .929 & - & - & \multirow{3}{*}{0.943} \\
\hline & The games started on time. & $\begin{array}{c}4.869 \\
(1.485)\end{array}$ & .956 & .031 & 35.534 & \\
\hline & The process of buying tickets was easy and fast. & $\begin{array}{c}4.811 \\
(1.540) \\
\end{array}$ & .880 & .035 & 28.449 & \\
\hline \multirow{3}{*}{$\begin{array}{l}\text { Physical } \\
\text { evidence }\end{array}$} & $\begin{array}{l}\text { The ambience of stadium and facility was excellent. } \\
\text { (e.g. lights, temperature, sounds, etc.) }\end{array}$ & $\begin{array}{c}6.121 \\
(1.189)\end{array}$ & .786 & - & - & \multirow{3}{*}{0.883} \\
\hline & The use of amenities was convenient and comfortable. & $\begin{array}{c}6.215 \\
(1.032)\end{array}$ & .901 & .049 & 20.146 & \\
\hline & Security inside and outside the stadium was excellent. & $\begin{array}{c}6.005 \\
(1.026) \\
\end{array}$ & .880 & .049 & 19.571 & \\
\hline \multirow{3}{*}{$\begin{array}{l}\text { Destination } \\
\text { Image }\end{array}$} & This city is an attractive destination. & $\begin{array}{c}5.914 \\
(1.078)\end{array}$ & .918 & - & - & \multirow{3}{*}{0.955} \\
\hline & $\begin{array}{l}\text { This city has quality infrastructure for international } \\
\text { sporting events. }\end{array}$ & $\begin{array}{l}5.982 \\
(1.083)\end{array}$ & .939 & .030 & 33.766 & \\
\hline & This city is trustworthy and safe. & $\begin{array}{c}5.914 \\
(1.138) \\
\end{array}$ & .953 & .031 & 35.412 & \\
\hline \multirow{3}{*}{ Satisfaction } & $\begin{array}{l}\text { Based on all of my experience in this event, } \\
\text { I am satisfied. }\end{array}$ & $\begin{array}{c}5.780 \\
(1.232)\end{array}$ & .803 & - & - & \multirow{3}{*}{0.865} \\
\hline & $\begin{array}{l}\text { All things considered, } \\
\text { my decision to attend this event was a wise one. }\end{array}$ & $\begin{array}{l}6.134 \\
(.933)\end{array}$ & .866 & .042 & 19.564 & \\
\hline & Overall, I am satisfied with this event. & $\begin{array}{c}5.922 \\
(1.054)\end{array}$ & .830 & .048 & 18.486 & \\
\hline \multirow{3}{*}{$\begin{array}{l}\text { Behavioral } \\
\text { Intention }\end{array}$} & I intend to attend other sporting events in this city again. & $\begin{array}{c}5.662 \\
(1.362)\end{array}$ & .907 & - & - & \multirow{3}{*}{0.956} \\
\hline & I intend to revisit this city again. & $\begin{array}{c}5.831 \\
(1.209)\end{array}$ & .954 & .027 & 34.419 & \\
\hline & I would love to come to this city again. & $\begin{array}{c}5.702 \\
(1.323) \\
\end{array}$ & .956 & .029 & 34.673 & \\
\hline
\end{tabular}


Table 3. Correlations of variables

\begin{tabular}{|c|c|c|c|c|c|c|c|c|c|c|c|}
\hline & 1 & 2 & 3 & 4 & 5 & 6 & 7 & 8 & 9 & AVE & $\mathrm{CR}$ \\
\hline 1. Product & 1 & & & & & & & & & .827 & .934 \\
\hline 2. Price & $0.230^{* * *}$ & 1 & & & & & & & & .568 & .798 \\
\hline 3. Place & $0.350^{* * *}$ & $0.421^{* * *}$ & 1 & & & & & & & .823 & .933 \\
\hline 4. Promotion & $0.373^{* * *}$ & $0.601^{* * *}$ & $0.536^{* * *}$ & 1 & & & & & & .619 & .829 \\
\hline 5. People & $0.288^{* * *}$ & $0.519^{* * *}$ & $0.786^{* * *}$ & $0.538^{* * *}$ & 1 & & & & & .605 & .820 \\
\hline 6. Process & $0.107^{* * *}$ & $0.439^{* * *}$ & $0.475^{* * *}$ & $0.554^{* * *}$ & $0.590^{* * *}$ & 1 & & & & .723 & .887 \\
\hline 7. PE & $0.429^{* * *}$ & $0.788^{* * *}$ & $0.572^{* * *}$ & $0.683^{* * *}$ & $0.424^{* * * *}$ & $0.497^{* * *}$ & 1 & & & .694 & .872 \\
\hline 8. DI & $0.457^{* * *}$ & $0.449^{* * *}$ & $0.811^{* * *}$ & $0.507^{* * *}$ & $0.722^{* * *}$ & $0.365^{* * *}$ & $0.558^{* * *}$ & 1 & & .857 & .947 \\
\hline 9. SAT & $0.454^{* * *}$ & $0.782^{* * *}$ & $0.615^{* * *}$ & $0.744^{* * *}$ & $0.846^{* * *}$ & $0.493^{* * *}$ & $0.829^{* * *}$ & $0.604^{* * *}$ & 1 & .660 & .854 \\
\hline 10. RI & $0.329^{* * *}$ & $0.465^{* * *}$ & $0.842^{* * *}$ & $0.554^{* * *}$ & $0.607^{* * * *}$ & $0.522^{* * *}$ & $0.528^{* * *}$ & $0.758^{* * *}$ & $0.634^{* * *}$ & .812 & .928 \\
\hline
\end{tabular}

Note: $* * * p<.001$; PE, Physical evidence; DI, Destination image; SAT, Satisfaction; RI, Revisit intention

1981). 〈Table 3〉에서 제시된 바와 같이 평균분산추출 값은 최저 .568에서 최고 .857, 개념신뢰도는 최저 .798에서 최고 .947로 나타나 모두 기준치를 초과하여 구성개념의 타당도를 확보하였다.

\section{상관관계 분석}

이 연구에서 설정한 요인 간의 상관관계를 파악하기 위하여 상관관계분석을 실시하였다. 〈Table 3〉와 같이 요인 간의 상관관계는 통계적으로 유의한 수준에서 $(p<.001)$ 정 $(+)$ 적인 상관관계를 보여주었다. 한편, 연 구에서 사용된 변수 간 상관관계가 일반적으로 8 이상, 보수적으로는 . 7 이상인 경우 높은 상관관계가 있다고 판 명되는데 이는 다중공선성 문제를 야기할 수도 있다 (Grewal, Cote, \& Baumgartner, 2004). 이 연구에서 는 장소와 개최도시이미지(.811), 장소와 재방문의도 (.842), 종사원과 관람만족(.846), 물리적 환경과 관람 만족(.829) 등에서 높은 상관관계가 나타났다. 이에 따 라 다중공선성 여부를 재확인하기 위해 추가적으로 공차 한계(Tolerance)와 분산팽창계수(VIF, variance inflation factor)를 활용하여 분석하였다. 다중공선성 판 단 기준으로 공차한계는 .1 미만, 분산팽창계수의 경우 엄격하게 5이상으로 적용하였다(Hair et al., 2010; Stevens, 2002). 분석 결과에 따르면 공차한계는 최소 .363에서 최대 .797, 분산팽창계수는 최소 1.254 에서
최대 2.752로 나타나 변인 간에는 다중공선성 문제가 없 는 것으로 확인되었다. 이와 함께 판별타당성은 〈Table $3\rangle$ 와 같이 모든 상관계수가 .85이하로 나타나 판별타당 성 또한 확보되었다(Kline, 2005).

\section{구조모형 검증}

이 연구에서 설정된 가설에 대해 통계적으로 수용 또 는 기각을 판단하기 위해 구조모형에 따라 검증될 통계적 모형을 설정하고 통계적 모형 설정결과에 따라 최대우도 법에 따른 구조모형 검증을 실시하였다. 이에 따라 모형 적합도는 $\mathrm{CMIN}$ 값은 1628.142 , 자유도 $(d f)$ 는 356으로 나타나 $\chi^{2} / d f=4.573$ 이며, $\mathrm{CFI}=.902, \mathrm{TLI}=.879$, $\mathrm{RMSEA}=.095, \mathrm{SRMR}=.084$ 로 나타났다. TLI는 적합 도 기준인 .9에 미치지 못하였으나 나머지 4 개 지수가 기 준을 충족함에 따라 이 연구의 모형은 측정모형과 등가 (equivalent)모형으로 적합하고, 이를 실증적으로 해석 하기에는 무리가 없다고 판단하였다(Bentler, 1990; Hu \& Bentler, 1999; Shevlin \& Miles, 1998; Wheaton, 1987).

\section{가설 검증}

이 연구가 제시한 연구모형에 대해 구조방정식모형분 석을 실시하였다. 그 결과는 〈Table 4〉와 〈Figure 2〉와 
Table 4. The results of hypotheses testing

\begin{tabular}{|c|c|c|c|c|}
\hline Path & Coefficient & $t$ & $p$ & Result \\
\hline \multicolumn{5}{|l|}{ H1: Marketing mix $\rightarrow$ Destination image } \\
\hline H1-1: Product $\rightarrow$ Destination image & $0.217^{* * *}$ & 4.584 & 0.000 & support \\
\hline H1-2: Price $\rightarrow$ Destination image & 0.043 & 0.809 & 0.419 & not support \\
\hline H1-3: Place $\rightarrow$ Destination image & $0.504^{* * *}$ & 10.23 & 0.000 & support \\
\hline H1-4: Promotion $\rightarrow$ Destination image & 0.020 & 0.428 & 0.669 & not support \\
\hline H1-5: People $\rightarrow$ Destination image & $0.200^{* * *}$ & 3.590 & 0.000 & support \\
\hline H1-6: Process $\rightarrow$ Destination image & -0.024 & -0.882 & 0.378 & not support \\
\hline H1-7: Physical evidence $\rightarrow$ Destination image & -0.007 & -0.091 & 0.927 & not support \\
\hline \multicolumn{5}{|l|}{$\mathrm{H} 2$ : Marketing mix $\rightarrow$ Satisfaction } \\
\hline H2-1: Product $\rightarrow$ Satisfaction & $0.145^{* * *}$ & 3.438 & 0.000 & support \\
\hline H2-2: Price $\rightarrow$ Satisfaction & $0.301^{* * *}$ & 6.088 & 0.000 & support \\
\hline H2-3: Place $\rightarrow$ Satisfaction & $0.107^{*}$ & 2.520 & 0.012 & support \\
\hline H2-4: Promotion $\rightarrow$ Satisfaction & $0.195^{* * *}$ & 4.549 & 0.000 & support \\
\hline H2-5: People $\rightarrow$ Satisfaction & 0.037 & 0.757 & 0.449 & not support \\
\hline H2-6: Process $\rightarrow$ Satisfaction & 0.034 & 1.410 & 0.158 & not support \\
\hline H2-7: Physical evidence $\rightarrow$ Satisfaction & $0.146^{*}$ & 2.238 & 0.025 & support \\
\hline H3: Destination image $\rightarrow$ Revisit intention & $0.374^{* * *}$ & 6.247 & 0.000 & support \\
\hline H4: Satisfaction $\rightarrow$ Revisit intention & $0.703^{* * *}$ & 13.428 & 0.000 & support \\
\hline
\end{tabular}

Note: ${ }^{* * *} p<.001,{ }^{* *} p<.01,{ }^{*} p<.05 ; \mathrm{CMIN}=1628.142, d f=356, \chi^{2} / d f=4.573, \mathrm{CFI}=.902, \mathrm{TLI}=.879, \mathrm{SRMR}=.084, \mathrm{RMSEA}=.095$

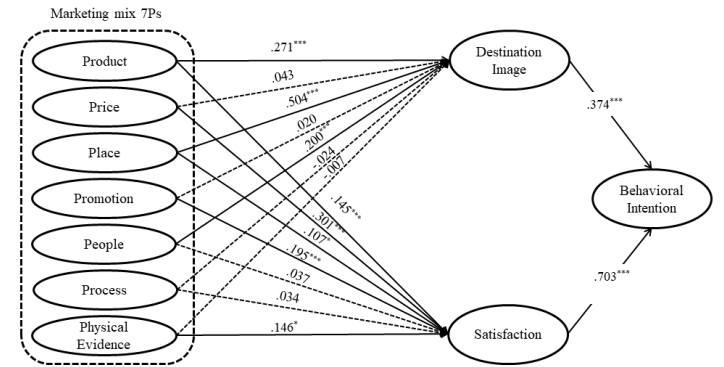

Fig. 2. The result of the proposed model

같다. 첫째, 세계수영선수권대회의 마케팅믹스 요인이 외래관광객의 개최도시이미지에 긍정적인 영향을 미칠 것이라고 설정한 가설 $(\mathrm{H} 1)$ 의 경우, 제품 $(\mathrm{H} 1-1)$, 장소 (H1-3), 종사원 $(\mathrm{H} 1-5)$ 이 개최도시이미지에 유의한 긍 정적 영향을 미치는 것으로 나타나 부분적으로 채택되었 다. 장소의 경로계수가 .504( $t$ 값 $=10.230, p=.000)$ 로
가장 높게 나타났고, 제품은 경로계수 .217, t값 4.584, $p=.000$, 종사원은 경로계수 $.200, t$ 값 $3.590, p=.000$ 으로 나타났다. 가격, 프로모션, 서비스과정, 물리적 환 경은 기각되었다. 둘째, 세계수영선수권대회의 마케팅믹 스 요인이 외래관광객의 관람만족에 긍정적인 영향을 미 칠 것이라는 가설 $(\mathrm{H} 2)$ 을 분석한 결과, 제품, 가격, 장소, 프로모션, 물리적 환경이 채택되고 종사원과 서비스과정 은 기각되었다. 가격 $(\mathrm{H} 2-2)$ 은 경로계수 .301, $t$ 값 $6.088, p=.000$ 으로 경로계수가 가장 높게 나타났다. 이 외에 프로모션 $(\mathrm{H} 2-4)$ 은 경로계수 195 , $t$ 값 4.549, $p=.000$, 물리적 환경 $(\mathrm{H} 2-7)$ 은 경로계수 $.146, t$ 값 $2.238, p=.025$, 제품 $(\mathrm{H} 2-1)$ 은 경로계수 .145 , $t$ 값 $3.438, p=.000$, 장소 $(\mathrm{H} 2-3)$ 는 경로계수 .107 , $t$ 값 $2.520, p=.012$ 로 나타나 채택되었다. 하지만 종사원 (H2-5)과 서비스과정 $(\mathrm{H} 2-6)$ 은 각각 경로계수 .037, $t$ 
값 $0.757, p=.449$ 와 경로계수 $.034, t$ 값 1.410 , $p=.158$ 로 나타나 기각되었다. 셋째, 세계수영선수권대 회 외래관광객의 개최도시이미지가 재방문의도에 긍정 적인 영향을 미칠 것이라고 설정한 가설 $(\mathrm{H} 3)$ 은 경로계수 가 $.374, t$ 값 $=6.247, p=.000$ 으로 나타나 채택되었다. 마지막으로, 세계수영선수권대회 외래관광객의 관람만 족이 재방문의도에 긍정적인 영향을 미칠 것이라는 가설 (H4)은 경로계수가 .703, $t$ 값 $13.428, p=.000$ 으로 나 타나 채택되었다.

\section{논 의}

\section{세계수영선수권대회 마케팅믹스와 개최도시이미지 간의 관계에 대한 논의}

먼저 세계수영선수권대회 마케팅믹스가 개최도시이미 지에 미치는 영향(H1)을 살펴본 결과 마케팅믹스 요인 중 제품, 장소, 종사원이 개최도시이미지에 유의한 정 $(+)$ 의 영향을 미치는 것으로 나타났다. 이는 골프장 내 장객에 대한 제품, 가격, 장소, 프로모션 등이 골프장 이 미지에 긍정적인 영향을 미친다고 밝힌 Lee and $\operatorname{Kang}(2016)$ 의 연구, 스포츠시설의 가격, 촉진, 제품 등 마케팅믹스가 스포츠시설 이미지의 선행요인임을 규명한 Mun and Cho(2011)의 연구를 부분적으로 지지한다.

Kim et al. (2016)은 해양스포츠이벤트 관람객을 대상 으로 한 연구에서 행사 진행요원의 전문성, 숙련도, 친절 등이 도시이미지를 높이는 요인이라고 규명하여 이 연구 의 결과를 지지해주고 있다. Kim and Cho(2014) 또한 국제요트대회의 시설과 종사원의 태도 등이 도시이미지 에 유의한 영향을 미치고 있다고 규명하여 이 연구의 결 과와 부분적으로 일치한다.

스포츠이벤트 개최도시의 이미지는 개인이 해당도시 를 방문하려고 고려할 때 떠오르는 총체적 지각으로 여행 과 관련한 의사결정에 큰 영향을 미친다(Crompton, 1979). Gwinner and Eaton(1999)에 따르면 스포츠이 벤트이미지와 도시이미지 간에는 이미지 유사성 (similarity)이 나타나 스포츠이벤트에 대한 지각이 도시 이미지로 전이되는데 관람객은 스포츠이벤트 참관 전에
갖고 있던 도시이미지를 이벤트 경험을 통해 더욱 강화시 킨다.

이 연구는 스포츠이벤트가 외래관광객들에게 제공하 는 박진감 넘치는 경기, 다양한 문화프로그램, 잘 정돈된 경기시설, 그리고 운영인력의 전문성과 친절성 등이 도시 이미지에 투영되어 도시이미지를 강화하는 역할을 한다 고 규명하였다. 즉 외국인 관람객들이 스포츠이벤트에 참 여하여 보고 즐기며 경험하는 제품·장소·인적자원 등의 유·무형적인 요인들이 이벤트와 개최도시이미지의 유사 성을 만들어 주는 결정적인 요인이었다. 따라서 세계적 수준의 경기장에서 각국의 내로라하는 유명선수들이 참 여하는 국제수영 대회를 성공적으로 개최한 것은 광주광 역시가 내세우는 세계적 수영도시 이미지를 구축하는데 크게 일조했다고 판단할 수 있다. 향후 광주광역시가 지 향하는 도시이미지를 확립하기 위해서는 경합의 묘미를 살려줄 수 있는 우수한 기량의 선수들을 적극적으로 초청 하고 대회수준에 걸맞은 시설환경을 구축하는 한편, 전통 문화행사, K-pop 콘서트 등 외국인 관람객들이 편하게 즐길 수 있는 다양한 오락적 체험요소를 지속적으로 제공 할 필요가 있다.

\section{세계수영선수권대회 마케팅믹스와 관람만족 간의 관 계에 대한 논의}

세계수영선수권대회 마케팅믹스가 관람만족에 미치는 영향 $(\mathrm{H} 2)$ 을 살펴본 결과 제품, 가격, 장소, 프로모션, 물 리적 환경이 관람만족에 유의한 정 $(+)$ 의 영향을 미치는 것으로 나타났다. 즉 스포츠이벤트의 마케팅믹스가 기대 이상의 성과를 나타낸다면 관람객의 이벤트 관람만족 또 한 높아진다는 것이다.

$\mathrm{F} 1$ 코리아 그랑프리 관람객을 대상으로 한 Lee, Park, and Bae(2015)의 연구는 경기내용의 매력성, 경 기장 접근성, 시설의 쾌적성, 비용, 촉진 등 경기관람요인 이 관람만족에 유의한 정 $(+)$ 적인 영향을 미친다고 밝혀 이 연구의 결과와 일치한다. Kwon et al.(2013)은 2011 대구 세계육상대회 관람객을 대상으로 한 연구에서 대회 의 경기내용과 관람편의성 등이 관람만족에 긍정적인 영 향을 미쳤다고 밝혔고, Kim and Park(2008)은 서울광 장에서 펼쳐진 세계여자스쿼시대회의 수준 높은 경기와 
흥미있는 이벤트뿐 아니라 서울광장의 야경과 어우러진 대회경기장이 관람객들의 만족에 유의한 영향을 준다고 규명하여 이 연구의 결과를 지지하고 있다. 이밖에 이 연 구의 결과는 4대 프로스포츠의 마케팅믹스와 관람만족 간 관계를 규명한 Roh et al.(2012)의 연구, 프로야구 관 람객을 대상으로 한 Kang(2017)과 Lee et al.(2017)의 연구, 프로축구 관람객을 대상으로 한 Cho and $\mathrm{Ha}(2020)$, Kwon and Jeng(2015)의 연구, $\mathrm{e}^{-}$스포츠 관 람객을 대상으로 한 Choi(2019)의 연구 등의 결과와 일 치하고 있다.

다른 스포츠이벤트 관련 선행연구와 이 연구의 결과를 통해 스포츠이벤트의 마케팅믹스는 관람만족에 영향을 미치는 중요한 선행요인으로 제시된다. 특히 개최도시이 미지에는 장소가 이미지유사성에 기반하여 가장 큰 영향 을 미치는 요인이었다면 관람만족의 경우 가격요인이 가 장 크게 영향을 미치고 있다. 스포츠나 관광상품의 경우 구매와 체험의 동시성으로 인해 관람객은 제품이나 서비 스 이용을 위해 지불한 비용과 그로부터 얻게 되는 편익 을 신속하게 평가한다. 따라서 제품과 서비스에 대한 지 불 가격 대비 기대 이상의 편익을 얻은 경우 관람만족에 큰 영향을 미치는 것이다. 아울러 국제스포츠이벤트의 경 우 입장료 외에도 식음료, 기념품 구입 등 다양한 가격요 인을 포함하고 있는데 고가판매가 아닌 외국인 관람객들 이 수긍할 수 있는 합리적인 가격으로 제시된다면 관람만 족이 크게 향상될 수 있다. 이와 함께 경기관람 외에 경기 장 인근에서 펼쳐지는 다양한 무료 공연, 전시회, 체험공 간 등이 지불비용 대비 얻게 되는 가치를 상승시켜 관람 만족에 긍정적인 영향을 미칠 수 있다. 이처럼 가격은 스 포츠이벤트의 마케팅믹스 중 이벤트운영조직이 가장 강 력하게 통제하여 사용할 수 있는 요인이므로(Kotler \& Armstrong, 2012), 이벤트 운영조직은 외래관광객들이 인지하고 평가하는 가격적 요인을 전반적으로 점검하고 적절한 가격이 책정될 수 있도록 해야 하며, 비가격적인 다양한 문화체험프로그램, 전통문화공연 등을 제공하여 외국인 관람객의 만족도를 높여줄 수 있는 방안을 강구해 야 할 것이다.

\section{개최도시이미지와 행동의도의 관계에 대한 논의}

관광지이미지는 관광객들이 관광지를 실제로 경험할 때까지 작용하며 관광지를 방문하려고 하는 결정과 그곳 에 대한 정보수집 활동을 촉진한다(Sunwoo \& Heo, 2011). 즉 이미지는 관광지 방문 전 관광지에 대한 기대 의 역할을 하게 되고 관광지의 경험은 기대치와 비교평가 를 통해 사후 관광행동에 영향을 주게 된다. 스포츠관광 과 관련된 다수의 연구는 관광지이미지에 대한 평가가 높 을수록 재방문의도나 구전의도와 같은 행동의도 또한 높 아진다고 보고하고 있다(Jeong \& Kim, 2019; Kaplanidou \& Vogt, 2007; Kim \& Goo, 2017; Kim et al., 2014; Kim et al., 2016; Koo, Byon, \& Baker, 2014; Min et al., 2020; Moon, 2016; Moon et al., 2013; Park \& Park, 2015). 관광객의 행동의도를 예측 하기 위한 핵심요인으로 지역이미지가 제시되고 있으며 지역이미지는 행동의도의 선행요인이자 마케팅믹스, 이 벤트품질 등의 선행요인에 따라 영향을 받는 종속변인으 로 활용되고 있는 것이다.

Dongfeng(2013)은 스포츠이벤트 기간을 맞이하여 상 하이를 방문한 외래관광객을 대상으로 개최지역이미지 와 재방문의도 간 관계를 조사한 결과 관광분위기, 관광 인프라 등의 개최지역이미지가 재방문의도에 유의한 영 향을 미친다고 밝혀 이 연구의 결과와 일치하였다. Kim and Goo(2017)의 경우 세계무예마스터십 관람객을 대 상으로 한 연구에서 스포츠이벤트가 도시 브랜드 가치를 높이는 마케팅기법으로 활용될 수 있으며 개최도시이미 지가 재방문의사에 긍정적 영향을 준다고 규명하여 이 연 구를 지지하고 있다. Jeong and $\operatorname{Kim}(2019)$ 은 경주 국 제마라톤대회 관람객 311 명을 대상으로 한 연구에서 경 주시의 안전성, 흥미성, 심미성 등 지역이미지가 재방문 의도에 유의한 영향을 미친다고 밝혀 이 연구와 같은 결 과를 보여주고 있다. 국제도로자전거대회 관람객을 대상 으로 한 Min et al.(2020)의 연구, 전주 국제배드민턴선 수권대회 관람객을 대상으로 한 Moon(2016)의 연구, 울 산 동아수영대회 관람객에 대한 Yoo(2012)의 연구 또한 관람객들이 지각한 개최지역이미지가 해당지역 재방문 의도의 선행요인이라고 밝혀 이 연구의 결과와 일치한다. 이처럼 다수의 선행연구와 이 연구의 결과는 스포츠이 
벤트를 통해 개최지역이 스포츠이벤트 인프라가 충분히 갖춰져 있고, 관광지역으로서 매력적이고 흥미로운 곳으 로 평가된다면 관람객의 재방문이 높아질 수 있다고 제시 한다. 따라서 스포츠이벤트 운영조직은 개최도시이미지 에 영향을 주는 선행요인을 체계적으로 관리하여 지역이 미지를 높여나가야 한다. 스포츠이벤트 유치부터 개최, 폐막까지 모든 과정을 다양한 미디어전략을 통해 신속하 게 확산하여 개최지역을 대내외에 알리고 스포츠스타와 홍보대사 등과 함께 적극적인 커뮤니케이션 활동을 펼쳐 스포츠관광지로서 이미지를 구축해나가야 할 것이다. 유 튜브, 페이스북, 블로그 등 인터넷 기반의 소셜미디어를 활용하여 대회정보를 제공하고, 관람객들의 경험과 의견 을 공유할 수 있는 공간을 활발하게 운영할 필요가 있다.

\section{만족도와 행동의도의 관계에 대한 논의}

세계수영선수권대회 외래관람객의 관람만족과 재방문 의도 간 관계를 규명한 결과 $(\mathrm{H} 4)$, 관람만족은 재방문의 도에 유의한 정 $(+)$ 적 영향을 미치는 것으로 나타났다. 이러한 연구결과는 국제스포츠이벤트 관람객의 관람만 족과 재방문의도 간 관계를 다룬 다수의 선행연구 결과와 일치한다(Biscaia et al., 2012; Clemes, Brush, \& Collins, 2013; Duan, Liu, \& He, 2018; Kwon et al., 2013; Lee et al., 2015; Lee et al., 2019; Lee, Cho, \& Oh, 2018; Tzetzis, Alexandris, \& Kapsampeli, 2013; Xiao et al., 2019; Yun \& Lee, 2009)

Lee et al. (2018)은 서울 장충체육관에서 열린 종합격 투기대회 관중을 대상으로 관람만족도와 재관람의도 간 관계를 규명한 결과 관람만족도가 재관람의도에 유의한 정 $(+)$ 의 영향을 미친다고 제시하였고, Lee et al. (2019)은 프로야구 원정경기 관람객을 대상으로 한 연구에서 경기관람 결정 만족, 경기관람 경험 만족 등의 관람만족이 재방문의사에 긍정적인 영향을 미친다고 규 명하여 이 연구의 결과를 지지하고 있다. 중국에서 개최 된 마라톤대회 관람객을 대상으로 한 Duan et al.(2018) 과 Xiao et al.(2019)의 연구 또한 관람만족과 재관람의 도가 통계적으로 유의한 관계가 있다고 밝혀 이 연구의 결과와 일치하고 있다. 이밖에 대구세계육상선수권 대회 관람객을 대상으로 한 Kwon et al. (2013)의 연구, 자동
차 경주대회 관람객에 대한 Han and $\operatorname{Kim}(2010)$ 의 연 구, 럭비대회 관중에 대한 Clemes et al.(2013)의 연구 등도 관람만족이 재방문의도의 핵심적인 선행요인임을 규명하여 이 연구의 결과를 지지하고 있다.

이처럼 스포츠이벤트 관람객의 재방문의도를 높이기 위해서는 관람객들이 경기관람 선택에 대한 만족감이나 기대 수준 이상의 만족감을 느낄 수 있는 다양한 마케팅 활동이 필요하다. 이와 함께 스포츠이벤트 운영조직은 겉 으로 잘 드러나지 않는 관람객들의 불만족 사례를 수집하 고 이를 해소하는 방안도 강구할 필요가 있다. 국제스포 츠이벤트에는 세계적 수준의 선수들이 참여하고 해당 대 회가 세계 곳곳에 방송되기 때문에 경기내용경기시설 등 과 관련된 분야에서는 만족도가 높게 나타나는 경향이 있 지만 경기 외적인 부분인 편의시설, 화장실, 주차시설, 셔 틀버스 등에서 낮은 만족도를 보이는 경향이 있기 때문에 (Kim \& Won, 2013), 대회 중 관람객들의 불만사항을 적극적으로 개선하여 관람만족을 높여야 할 것이다. 특히 외국인 관람객의 경우 언어와 관련된 불만사항이 나타나 는 경향이 크기 때문에 통역이나 안내문구 등에 대한 적 절한 대응이 필요할 것이다.

\section{결론 및 제언}

이 연구는 우리나라에서 최초로 개최된 2019 광주 FINA 세계수영선수권대회의 마케팅믹스와 개최도시이 미지, 관람만족, 재방문의도 간 구조적 관계를 규명하였 다. 특히 국제스포츠이벤트라는 취지에 맞도록 대회 기간 동안 한국을 방문한 외래관광객들 대상으로 연구를 진행 하였다. 아울러, Booms and Bitner(1981)가 제시한 마 케팅믹스 $7 \mathrm{P}$ 를 기반으로 무형재이자 스포츠소비자의 경 험, 소비가 핵심인 스포츠이벤트에 적용 가능한 다양한 마케팅믹스 요인을 발굴하여 관람객의 소비심리행동 예 측을 위한 선행요인으로 활용하였다.

요약된 연구결과는 다음과 같다. 첫째, 세계수영선수 권대회 마케팅믹스 요인 중 제품, 장소, 종사원은 관람객 의 개최도시이미지에 긍정적인 영향을 미친다. 둘째, 세 계수영선수권대회 마케팅믹스 요인 중 제품, 가격, 장소, 프로모션, 물리적 환경은 관람객의 관람만족에 긍정적인 
영향을 미친다. 셋째, 세계수영선수권대회 관람객의 지 각된 개최도시이미지와 관람만족은 각각 재방문의도에 긍정적인 영향을 미친다.

이러한 연구결과는 국제스포츠이벤트의 성공적 개최 뿐 아니라 개최지역이미지 제고, 관광객의 지속적 유입 등 개최효과를 창출하기 위해서는 스포츠마케팅의 핵심 적인 마케팅 수단인 마케팅믹스를 잘 활용하여 관람객들 에게 기억에 남을만한 이벤트 경험을 제공하고 관람객들 의 만족도를 높여야 한다는 것을 보여준다. 특히 전통적 인 마케팅믹스 $4 \mathrm{P}$ 뿐 아니라 스포츠이벤트에 알맞은 보다 차별화된 마케팅믹스 기반의 마케팅전략을 수립하고 이 를 체계적으로 추진해야 한다.

국제스포츠이벤트는 내국인 관람객 외에도 수많은 외 국인 관광객이 찾는다. 이들이 기대하는 경기수준을 위해 우수선수를 초청하고 대회의 수준을 보다 격상시킬 필요 가 있다. 적재적소에서 관람서비스를 제공하는 자원봉사 자의 품질을 높이기 위해 기본소양교육 등을 사전에 철저 히 진행한다. 광주광역시가 경기현장에서 긴박한 외국어 통역이 필요한 경우를 대비해 운영한 이동 통역서비스 자 원봉사단은 운영인력에 대한 외래관람객의 만족도를 높 이는 방법이었다. 이와 함께 경기입장료, 기념품 비용 등 가격적 요인을 합리적으로 책정하고 비가격적 측면의 다 양한 즐길거리를 지속적으로 제공하여 관람을 위해 지불 한 비용 대비 이벤트로부터 높은 가치를 지각하도록 해야 할 것이다. 끝으로 메가 국제스포츠이벤트를 개최하면서 발굴한 다양한 광고·홍보 전략이나 노하우 등을 다른 지 자체와 적극적으로 공유하여 향후 유사대회에서 이를 활 용할 수 있도록 돕는 것도 필요하다. 이를 통해 국제스포 츠이벤트가 해외 관광객을 유치하는 중요한 수단으로 거 듭날 수 있을 것이다.

이 연구가 갖는 한계점을 바탕으로 후속연구를 위해 다음과 같이 제언하고자 한다. 먼저 이 연구는 마케팅믹 스를 활용한 선행연구를 기반으로 마케팅믹스와 스포츠 소비자행동 의사결정과의 인과관계를 살펴보고 있다. 스 포츠분야에서 마케팅믹스를 활용한 여러 연구가 진행되 고 있는 점을 감안하여 연구결과를 통합적으로 비교한 메 타연구가 제시될 필요가 있으며 이를 기반으로 마케팅믹 스와 종속변인 간의 체계화된 영향관계를 정립해 보는 것 이 의미 있을 것이다. 아울러, 이 연구가 외국인 관광객을
대상으로 진행되고 외국인 관광객의 행동의도를 예측하 기 위해 시도되었는데, 마케팅믹스, 지역이미지, 관람만 족 등이 국가별 편차가 있을 수 있으므로 향후 국제스포 츠이벤트 개최 시 외국인의 국적별 표본을 충분히 수집하 여 국적에 따른 조절효과를 분석해보는 것도 중요하다. 이를 통해 국가 또는 대륙별 외래관광객을 대상으로 한 핵심적인 마케팅믹스 요인을 도출하고 이들을 대상으로 차별화된 마케팅믹스를 제공하여 관람만족도를 더욱 높 여나갈 수 있을 것이다. 또한 내국인과 외국인 관광객 간 의 비교연구도 의미가 있다고 본다. 마지막으로 스포츠이 벤트를 대상으로 한 구조방정식 모형에서 마케팅믹스 7P 외에 이벤트 속성, 이벤트 환경 등 다양한 선행요인을 발 굴하고 종속변수로 관람객의 즐거움, 신뢰, 관람몰입, 이 벤트이미지, 국가이미지 등 다양한 요인을 활용할 필요가 있다. 국제스포츠이벤트와 관련한 이론적 모형을 검증하 여 이론뿐 아니라 실무에도 기여할 수 있는 후속연구가 지속적으로 진행되어야 할 것이다.

\section{참고문헌}

Aaker, D. A. (1991). Managing brand equity: Capitalizing on the value of a brand name. New York, NY: The Free Press.

Allameh, S. M., Khazaei Pool, J., Jaberi, A., Salehzadeh, R., \& Asadi, H. (2015). Factors influencing sport tourists' revisit intentions: The role and effect of destination image, perceived quality, perceived value and satisfaction. Asia Pacific Journal of Marketing and Logistics, 27(2), 191-207.

Baek, S. H., \& Kim, G. T. (2016). An analysis of the importance and satisfaction of the 6Cs of marketing mix for professional baseball grounds using IPA analysis. Journal of Sport and Leisure Studies, 64, 259-271.

Baker, D. A., \& Crompton, J. L. (2000). Quality, satisfaction and behavioral intentions. Annals of Tourism Research, 27(3), 785-804.

Baloglu, S., \& Brinberg, D. (1997). Affective images of tourism destinations. Journal of Travel Research, 35(4), $11-15$.

Bentler, P. M. (1990). Comparative fit indexes in structural models. Psychological Bulletin, 107(2), 238-246.

Bentler, P. M., \& Bonett, D. G. (1980). Significance tests and 
goodness of fit in the analysis of covariance structures. Psychological Bulletin, 88(3), 588-606.

Biscaia, R., Correia, A., Rosado, A., Maroco, J., \& Ross, S. (2012). The effects of emotions on football spectators' satisfaction and behavioural intentions. European Sport Management Quarterly, 12(3), 227-242.

Booms, B. H., \& Bitner, M. J. (1981). Marketing strategies and organization structures for service firms, in J. H. Donnelly and W. R. George (eds) Marketing of Services, pp. 47-51. Chicago, IL: American Marketing Association.

Borden, N. H. (1964). The concept of the marketing mix. Journal of Advertising Research, 4(2), 2-7.

Buhler, A. \& Nufer, G. (2009). Relationship marketing in sport. Oxford: Butterworth-Heinemann.

Byon, K. K., \& Zhang, J. J. (2010). Development of a scale measuring destination image. Marketing Intelligence \& Planning, 28(4), 508-532.

Chalip, L., Green, B. C., \& Hill, B. (2003). Effects of sport event media on destination image and intention to visit. Journal of Sport Management, 17(3), 214-234.

Cheon, D. H. (2020). A study on the effects of marketing mix on brand image, customer satisfaction, and loyalty in the outbound travel industry. International Journal of Tourism and Hospitality Research, 34(5), 111-124.

Cho, Y. W., \& Ha, J. H. (2020). The Influence of marketing mix factor on spectating satisfaction, team loyalty, and revisit intention for professional football clubs. The Korean Journal of Sport, 18(2), 1235-1254.

Choi, D. O. (2019). A Study on the effects of watching e-sports on satisfaction, preference, reuse intention in college students: A focus on marketing mix factors. The e-Business Studies, 20(2), 133-144.

Chung, H. J. (2008). Sports mega-events and economic impact: Reconstruction of invented truth. Korean Society for the Sociology of Sport, 21(1), 229-251.

Clemes, M. D., Brush, G. J., \& Collins, M. J. (2011). Analysing the professional sport experience: A hierarchical approach. Sport Management Review, 14(4), 370-388.

Crompton, J. L. (1979). Motivations for pleasure vacation. Annals of Tourism Research, 6(4), 408-424.

Dongfeng, L. (2013). Major sports events, destination image and intention to revisit from the foreign tourist's perspective. International Journal of Sports Marketing \&
Sponsorship, 14(3), 23-34.

Dong, Q., \& Duysters, G. (2015). Research on the co-branding and match-up of mega-sports event and host city. The International Journal of the History of Sport, 32(8), 1098-1108.

Duan, Y., Liu, B., \& He, Y. (2019). Study on relationships among sports spectator motivations, satisfaction, and behavioral intention. International Journal of Sports Marketing and Sponsorship, 21(3), 409-425.

Echtner, C. M., \& Ritchie, J. R. (2003). The meaning and measurement of destination image. Journal of Tourism Studies, 14(1), 37-48.

Fishbein, M., \& Ajzen, I. (1975). Belief, attitude, intention, and behavior: An introduction to theory and research. Reading, MA: Addison-Wesley.

Fisk, R. P., Brown, S. W., \& Bitner, M. J. (1993). Tracking the evolution of the services marketing literature. Journal of Retailing, 69(1), 61-103.

Fornell, C., \& Larcker, D. F. (1981). Structural equation models with unobservable variables and measurement error: Algebra and statistics. Journal of Marketing Research, 18(3), 382-388.

Fourie, J., \& Santana-Gallego, M. (2011). The impact of mega-sport events on tourist arrivals. Tourism Management, 32(6), 1364-1370.

Getz, D. (1991). Festivals, special events, and tourism. New York, NY: Van Nostrand Reinhold.

Getz, D. (1997). Trends and issues in sport event tourism. Tourism Recreation Research, 22(2), 61-62.

Grewal, R., Cote, J. A., \& Baumgartner, H. (2004). Multicollinearity and measurement error in structural equation models: Implications for theory testing. Marketing Science, 23(4), 519-529.

Grönroos, C. (1987). Developing the service offering: A source of competitive advantage. In Surpranant, C. (ed), Addvalue to your service. Chicago, IL: American Marketing Association.

Gwangju city (2019). FINA Official Programme. https://www.gwangju2019.com/home/www/down/program book.pdf

Gwinner, K. P., \& Eaton, J. (1999). Building brand image through event sponsorship: The role of image transfer. Journal of Advertising, 28(4), 47-57. 
Hair, J. F., Anderson, R. E., Babin, B. J., \& Black, W. C. (2010). Multivariate data analysis: A global perspective (Vol. 7). Upper Saddle River, NJ: Pearson.

Han, S. H., \& Kim, I. J. (2010). The relationships among spectator factors and repeat watching of car racing spectators. Korean Society For Sport Management, 15(2), 77-89.

Hoffman, K. D., \& Bateson, J. E. (2010). Services marketing: Concepts, strategies, \& cases. Mason, OH: South-Western Cengage Learning.

Hu, L. T., \& Bentler, P. M. (1999). Cutoff criteria for fit indexes in covariance structure analysis: Conventional criteria versus new alternatives. Structural Equation Modeling: A Multidisciplinary Journal, 6(1), 1-55.

Hwang, J., Yoon, Y. H, Yoon, Y. S., \& Song, R. H. (2015). A study on influence of convention destination marketing mix on image and loyalty. The Korean Society of Science \& Art, 19, 735-745.

Jang, K. S., \& Hong, K, H. (2009). The effects of sports event service quality on the participants' satisfaction, local image and behavioral intention. Korean Journal of Business Administration, 22(5), 3111-3128.

Jeong, Y., \& Kim, S. K. (2019). The key antecedent and consequences of destination image in a mega sporting event. South African Journal of Business Management, 50(1), $1-11$.

Kang, J. K. (2017). The relationship among marketing mix, relational quality and post-viewing behavior in professional baseball team. The Korean Journal of Sports Science, 26(3), 689-700.

Kang, S. K. (2011). International sports event and urban tourism. Journal of the Korean Regional Economics, 18, 67-85.

Kaplanidou, K., \& Vogt, C. (2007). The interrelationship between sport event and destination image and sport tourists' behaviours. Journal of Sport \& Tourism, 12(3-4), 183-206.

Kaplanidou, K., Jordan, J. S., Funk, D., \& Ridinger, L. L. (2012). Recurring sport events and destination image perceptions: Impact on active sport tourist behavioral intentions and place attachment. Journal of Sport Management, 26(3), 237-248.

Kelloway, E. K. (1995). Structural equation modelling in perspective. Journal of Organizational Behavior, 16(3), 215-224.

Kim, J. D. (2019). Gwangju FINA World Championships watched by people all over the world, Jeonnam-ilbo, https://jnilbo.com/view/media/view?code=2019122213530 666071

Kim, G. H., \& Han, J. W. (2016). The effect of marketing mix of sports center in a company on customer satisfaction and customer loyalty. Korean Journal of Sports Science, 25(1), 725-737.

Kim, H. R., \& Goo, K. B. (2017). The effect of service quality of martial arts masterships and image of host city on reputation and revisit intention. Journal of Sport and Leisure Studies, 68, 135-146.

Kim, H. R., \& Won, D. Y. (2013). The influences of factors related to spectator attendance on perceived value and revisit intention in F1 Korea grand prix. The Korean Journal of Physical Education, 52(1), 213-225.

Kim, H. S., \& Park, Y. B. (2008). The effects of sports events at the seoul plaza on the image and royalty, satisfaction of the region. The Korean Journal of Physical Education, 47(1), 251-261.

Kim, H. Y., \& Yang, G. S. (2015). A study on urban tourism satisfaction and attitude of the marketing mixed factor: Focused on domestic \& foreign tourists visiting in Gwangju. International Journal of Tourism and Hospitality Research, 29(5), 117-132.

Kim, J. B., \& Cho, W. J. (2014). The effects of marine sport event's appraisal attributes on city marketing ssset and city marketing effectiveness. Korean Society for Sport Management, 19(6), 1-15.

Kim, C. R., Nam, Y. J., \& Byun, Y. S. (2016). The effect of marine sport event visitors' satisfactions on reinforcement of a city image and a community consiousness. The Korean Journal of Physical Education, 55(1), 97-105.

Kim, C. Y., Kim, H. N., \& Kim, E. H. (2020). The effect of marketing mix through convergence performance by national dance company of Korea on spectator satisfaction and revisiting intention. Korean Journal of Dance, 20(2), 25-39.

Kim, J., Kang, J. H., \& Kim, Y. K. (2014). Impact of mega sport events on destination image and country image. Sport Marketing Quarterly, 23(3), 161-175. 
Kim, S. K., Park, J. A., \& Kim, W. (2016). The mediating effect of destination image on the relationship between spectator satisfaction and behavioral intentions at an international sporting event. Asia Pacific Journal of Tourism Research, 21(3), 273-292.

Kim, S. K., Yoo, J. G., \& Park, J. A. (2016). The relationship among marketing mix, satisfaction, repurchase intention, and word-of-mouth intention at gala show. Korean Journal of Sport Science, 27(1), 121-132.

Koo, K. Y. (2019). Mayor Lee Yong-seop said "Gwangju Worldchampions was the most successful swimming competitions. thanks for citizenship". Newsis. https://newsis.com/view/?id=NISX20190819_0000744078 $\& \mathrm{cID}=10899 \& \mathrm{pID}=10800$

Koo, S. K., Byon, K. K., \& Baker, T. A. (2014). Integrating event image, satisfaction, and behavioral intention: Small-scale marathon event. Sport Marketing Quarterly, 23(3), 127-137.

Korea Tourism Organization (KTO, 2020) http://kto.visitkorea. or.kr/kor/ktom/stat/stat.kto

Kotler, P., \& Armstrong, G. (2012). Principles of marketing (14th ed). Harlow: Pearson.

Kotler, P., \& Keller, K. L. (2016). Marketing management (15th ed.). Harlow: Pearson.

Kwon, O. K., \& Jeng, Y. D. (2015). The effect of marketing mix factor of professional football second division on spectator satisfaction and re-attend intention. The Korean Journal of Sport, 13(4), 149-160.

Kwon, W., Kim, Y. D., \& Park, S. I. (2013). The impact of mega-sporting events service quality and spectator satisfaction on sport consumption behaviors: The case of the 2011 International Association of Athletics Federations (IAAF) World Championship. Korean Society for Sport Management, 18(1), 15-27.

Kwon, W., Lee, H. W., \& Kim, M. J. (2013). F1 in a global context: A cross-cultural examination of marketing activities and behavioral intentions. The Korean Journal of Physical Education, 52(3), 251-266.

Kwon, K. S., Oh, T. Y., Ahn, J. S., \& Bang, S. W. (2015). What drives fans? Effect of service marketing mix on revisit intentions: The case of K-league Classic. Korean Society For Sport Management, 20(3), 45-61.

Jeong, Y., \& Kim, S. (2019). A study of event quality, destination image, perceived value, tourist satisfaction, and destination loyalty among sport tourists. Asia Pacific Journal of Marketing and Logistics, 32(4), 940-960.

Lee, K. H., \& Moon, B. Y. (2017). The impact of spectator's satisfaction of marine sport event on host destination image and behavioral intention. Journal of Hotel \& Resort, 16(3), 283-304.

Lee, Y. B., \& Kang, S. H. (2016). The effects of the factors of the golf tourism marketing mix on golf course image and golf tourist satisfaction: Golf tourists at the "L" golf course, Jeonnam province, as a case. International Journal of Tourism and Hospitality Research, 30(9), 1738-3005.

Lee, C. K., Lee, Y. K., \& Lee, B. (2005). Korea's destination image formed by the 2002 World Cup. Annals of Tourism Research, 32(4), 839-858.

Lee, J. H., Kim, S. Y., \& Yoo, Y. H. (2017). The effects of a pro-baseball team's mixed marketing factors on spectators' team brand loyalty and spectating satisfaction. Journal of Korean Association of Physical Education and Sport for Girls and Women, 31(4), 119-138.

Lee, J. H., Lee, Y. G., \& Lee, J. H. (2012). The effect of marketing mix factor in dance performing hall on audience's satisfaction and re-watch intension. Korean Society of Sport and Leisure Studies, 48(1), 279-289.

Lee, K. M., Jeon, Y. B., \& Kim, S. Y. (2017). The relationships among marketing mix, constraints, and consumers 'revisiting intentions: Focusing on screen sport theme parks. Journal of the Korea Contents Association, 17(2), 473-484.

Lee, K. Y., Park, S. J., \& Bae, S. W. (2015). A study on the structural relationship between factors related to spectator attendance, satisfaction, affective image and revisit intention in F1 Korea grand prix. Journal of Sport and Leisure Studies, 61, 237-248.

Lee, S. J., Cha, J. H., Chang, K. R., \& Seo, W. J. (2019). The effect of physical environment of professional baseball stadium on spectators' satisfaction, and revisit intention: Focusing on away games in Korea professional baseball. Korean Journal of Sport Management, 24(6), 1-14.

Lehto, X. Y., O’Leary, J. T., \& Morrison, A. M. (2004). The effect of prior experience on vacation behavior. Annals of Tourism Research, 31(4), 801-818.

Li, F. B., Cho, K. M., \& Jang, W. Y. (2018). The relationship 
among service quality, participants' satisfaction, regional image and intentions of re-participation of international marathon events: Focused on Chinese participants. The Korean Journal of Sports Science, 27(1), 39-56.

Lovelock, C., Patterson, P., \& Wirtz, J. (2015). Services marketing (6th ed.). Melbourne: Pearson Australia.

MacKay, K. J., \& Fesenmaier, D. R. (2000). An exploration of cross-cultural destination image assessment. Journal of Travel Research, 38(4), 417-423.

McCarthy, E. J. (1964). Basic Marketing. Homewood, IL: Richard D. Irwin.

Min, D. S., \& Lee, W. Y. (2019). Examining the impact of event quality on spectators' destination image, country image and behavioral intention: A case of Tour de Korea. Korean Journal of Sport Science, 30(1), 90-104.

Min, D. S., Ko, J. M., \& Lee, W. Y. (2020). Examining the structural relationships between international sporting event experience, perceived value, destination image, satisfaction and behavioral intention. The Korean Journal of Physical Education, 59(3), 243-261.

Ministry of Culture, Sports and Tourism (MCST, 2019). Expected to attract 17.5 million foreign tourists, the largest ever in 2019. https://www.mest.go.kr/kor/s_notice/ press/pressView.jsp?pSeq $=17722 \&$ MenuCD $=0302000000$ $\&$ CurrentPage $=7 \&$ TypeDept $=\&$ pSearchType $=01 \& p S e a r$ chWord $=\%$ EA $\%$ B4 $\% 80 \%$ EA $\%$ B4 $\% 91$

Moon, K. S. (2016). The relationships among regional international sport event quality, destination image, and behavioral intention. The Korean Journal of Sports Science, 25(1), 619-637.

Moon, K. S., Ko, Y. J., Connaughton, D. P., \& Lee, J. H. (2013). A mediating role of destination image in the relationship between event quality, perceived value, and behavioral intention. Journal of Sport \& Tourism, 18(1), 49-66.

Moutinho, L., \& Witt, S. F. (1989). Tourism marketing and management handbook. Upper Saddle River, NJ: Prentice Hall.

Mun, S. H., \& Cho, T. S. (2011). Influence of marketing mix of a sports facility on its sports facility image and user attitude. Journal of Sport and Leisure Studies, 46, 103-116.

Mullin, B. J., Hardy, S., \& Sutton, W. (2014). Sportmarketing (4th edition). Champaign, IL: Human Kinetics.
Nunnally, J. C., \& Bernstein, I. (1994). Psychometric theory (3rd ed.). New York, NY: McGraw Hill.

Oliver, R. L. (1997). Satisfaction: A behavioral perspective on the consumer. New York, NY: McGraw Hill.

Oppermann, M. (2000). Tourism destination loyalty. Journal of Travel Research, 39(1), 78-84.

Park, E. Y. (2009). The study on figure skating`s marketing $\operatorname{mix}(4 \mathrm{P}$ 's), spectator satisfaction and recommendation intention: about figure skating final Goyang Korea 2008. Journal of Sport and Leisure Studies, 38(1), 223-234.

Park, S. J. (2020). Gwangju city spurs legacy business at the 2019 swimming. Jeonnam-Ilbo, https://www.jnilbo.com/ view/media/view?code $=2020072115473234886$

Park, J. K., \& Park, S. Y. (2015). Structural relationships among service quality of sports events and host city image, reputation and revisit intention: Revolving around sports events held in small and medium sized cities. Journal of Sport and Leisure Studies, 60, 293-304.

Perdersen, P. M., Miloch, K. S., \& Laucella, P. C. (2007). Strategic Sport Communication. Champaign, IL: Human Kinetics.

Pine, B. J., \& Gilmore, J. H. (1999). The experience economy: work is theatre \& every business a stage. Boston, MA: Harvard Business Press.

Rafiq, M., \& Ahmed, P. K. (1995). Using the 7Ps as a generic marketing mix. Marketing Intelligence \& Planning, 13(9), 4-15.

Roche, M. (1994). Mega-events and urban policy. Annals of Tourism Research, 21(1), 1-19.

Roh, D. Y., Kim, T. I., \& Park, S. B. (2012). The relationship among marketing strategy, viewing satisfaction and revisit intention of professional sports teams. Korean Journal of Sports Science, 21(4), 67-79.

Ross-Wooldridge, B., Brown, M. P., \& Minsky, B. D. (2004). The role of company image as brand equity. Corporate Communications: An International Journal, 9(2), 159-167.

Shevlin, M., \& Miles, J. N. (1998). Effects of sample size, model specification and factor loadings on the GFI in confirmatory factor analysis. Personality and Individual Differences, 25(1), 85-90.

Shoemaker, S., \& Lewis, R. C. (1999). Customer loyalty: the future of hospitality marketing. International Journal of Hospitality Management, 18(4), 345-370. 
Son, S. W. (2020). 2019 Gwangju FINA World Championships, with 15.9 billion won surplus. Yonhop News. https://www.yna.co.kr/view/AKR202007160713000 54?input $=1195 \mathrm{~m}$

Stevens, J. (2002). Applied multivariate statistics for the social sciences (4th ed.). Mahwah, NJ: Lawrence Erlbaum Associates

Sunwoo, Y. S., \& Heo, C. U. (2011). The effects of brand equity of sports events on the regional images and attitude in the hosting city: The case of 2010 Chuncheon World Leisure Games. Korean Journal of Tourism Research, 26(4), 333-349

Tzetzis, G., Alexandris, K., \& Kapsampeli, S. (2014). Predicting visitors' satisfaction and behavioral intentions from service quality in the context of a small-scale outdoor sport event. International Journal of Event and Festival Management, 5(1), 4-21.

Wakefield, K. L., \& Blodgett, J. G. (1994). The importance of servicescapes in leisure service settings. Journal of Services Marketing, 10(6), 45-61.

Wakefield, K. L., Blodgett, J. G., \& Sloan, H. J. (1996). Measurement and management of the sportscape. Journal of Sport Management, 10(1), 15-31.

Wheaton, B. (1987). Assessment of fit in overidentified models with latent variables. Sociological Methods and Research, 16(1), 118-154.

Worcester, R. M. (1997). Managing the image of your bank: The glue that binds. International Journal of Bank Marketing, 15(5), 146-152.

Xiao, Y., Ren, X., Zhang, P., \& Ketlhoafetse, A. (2019). The effect of service quality on foreign participants' satisfaction and behavioral intention with the 2016 Shanghai International Marathon. International Journal of Sports Marketing and Sponsorship, 21(1), 91-105.

Yoo, Y. S. (2012). The effect of service quality of sport event and destination image of host city on sport tourists' satisfaction and revisit intention. The Korean Journal of Sports Science, 21(3), 499-511.

Yoon, J., \& Lim, K. U. (2009). The influence of a marketing mix of tourist spot and a tourism image on a visitor's intention to make a second visit. Korean Journal of Hospitality \& Tourism, 18(4), 261-285.

Yoon, W. S., \& Chang, Y. C. (2009). The relationships between marketing mix factors of private sports centers, satisfaction with the centers and intention to reuse. Korean Journal of Sports Science, 18(1), 561-569.

Yu, J. H. (2019). Why was the high diving stage located in Chosun university?. Honam-ilbo, http://honam.co.kr/detail NDULL4/611087

Yun, J. K., \& Lee, Y. C. (2009). The effects of spectating environment of community sports events on spectating contentment and spectating adherence behaviour. Journal of Sport and Leisure Studies, 37(1), 497-508.

Zeithaml, V. A., Berry, L. L., \& Parasuraman, A. (1996). The behavioral consequences of service quality. Journal of Marketing, 60(2), 31-46.

Zhang, J. J., Kim, E., Mastromartino, B., Qian, T. Y., \& Nauright, J. (2018). The sport industry in growing economies: critical issues and challenges. International Journal of Sports Marketing and Sponsorship, 19(2), 110-126. 


\title{
국제스포츠이벤트의 마케팅믹스(7P)가 외래관광객의 개최도시이미지, 관람만족, 재방문의도에 미치는 영향: 2019 광주 FINA 세계수영선수권대회를 중심으로
}

\author{
민두식 \\ 한양대학교 겸임교수
}

[목적] 이 연구의 목적은 2019 광주 FINA 세계수영선수권대회의 마케팅믹스(7P) 요인과 외래관광객의 개최도시이미지, 관람만족, 재방문의도 간 구조적 관계를 살펴보기 위한 것이다. 〔방법) 2019년 7월, 대회를 관람하기 위해 방문한 외래관광객 415 명을 대상으로 설문조사를 진행하고 396 부를 최종 유효표본으로 사용 하였다. SPSS 22.0과 AMOS 22.0을 통해 인구통계, 조사도구의 타당성, 상관관계, 인과관계 등을 분석하였 다. 〔결과〕 이 연구는 분석을 통해 다음과 같은 결과를 도출하였다. 첫째, 마케팅믹스 중 제품, 장소, 종사원은 외래관광객의 개최도시이미지에 유의한 정 $(+)$ 의 영향을 미쳤다. 둘째, 마케팅믹스 중 제품, 가격, 장소, 프로 모션, 물리적 환경은 외래관광객의 관람만족에 유의한 정 $(+)$ 의 영향을 미쳤다. 셋째, 외래관광객의 개최도시 이미지는 재방문의도에 유의한 정 $(+)$ 의 영향을 미쳤다. 넷째, 외래관광객의 관람만족은 재방문의도에 유의한 정 $(+)$ 의 영향을 미쳤다. 〔결론〕 이 연구는 국제스포츠이벤트의 마케팅믹스 요인이 외래관광객의 개최도시이 미지와 관람만족에 직접적으로 영향을 미치고 개최도시이미지와 관람만족을 매개로 재방문의도에 간접적으로 영향을 미치는 것을 규명하였다. 따라서 스포츠이벤트를 통해 관광객 유입 확대, 지역경제 활성화 등의 목적을 달성하기 위해서는 지자체나 이벤트 운영조직이 마케팅믹스를 전략적으로 활용하여 외래관람객의 관람만족을 높여나가야 할 것이다.

주요어: 스포츠이벤트 마케팅믹스, 개최도시이미지, 관람만족, 재방문의도, FINA 세계수영선수권대회 